\title{
Caddo Ceramics from Mound Deposits at the Shelby Mound Site (41CP71) on Greasy Creek, Camp County, Texas
}

Timothy K. Perttula

Heritage Research Center, Stephen F. Austin State University

Follow this and additional works at: https://scholarworks.sfasu.edu/ita

Part of the American Material Culture Commons, Archaeological Anthropology Commons, Environmental Studies Commons, Other American Studies Commons, Other Arts and Humanities Commons, Other History of Art, Architecture, and Archaeology Commons, and the United States History Commons

Tell us how this article helped you.

This Article is brought to you for free and open access by the Center for Regional Heritage Research at SFA ScholarWorks. It has been accepted for inclusion in Index of Texas Archaeology: Open Access Gray Literature from the Lone Star State by an authorized editor of SFA ScholarWorks. For more information, please contact cdsscholarworks@sfasu.edu. 


\section{Caddo Ceramics from Mound Deposits at the Shelby Mound Site (41CP71) on Greasy Creek, Camp County, Texas}

\section{Creative Commons License}

\section{(c) (1) (8)}

This work is licensed under a Creative Commons Attribution-NonCommercial 4.0 International License 


\title{
Caddo Ceramics from Mound Deposits at the Shelby Mound Site (41CP71) on Greasy Creek, Camp County, Texas
}

\author{
Timothy K. Perttula
}

\section{INTRODUCTION}

Archaeological evidence from $15^{\text {th }}$ to $17^{\text {th }}$ century (dating from ca. A.D. 1430-1680) Caddo sites that have been investigated in the Big Cypress Creek and Sabine River basins of northeastern Texas indicate that many of the components have been identified as belonging to the Titus phase. They represent permanent, year-round, settlements of horticultural or agricultural peoples with distinctive cultural practices and material culture (Perttula 2012). The $15^{\text {th }}$ to $17^{\text {th }}$ century archaeological record in these two basins "refers to a number of distinctive socio-cultural groups, not a single Caddo group; these groups or communities were surely related and/or affiliated by kinship, marriage, and social interaction" (Perttula 2005:401). There are several clusters of settlements that apparently represent parts of contemporaneous small communities. A political community as used here is a cluster of interrelated settlements and associated cemeteries that are centered on a key site or group of sites distinguished by public architecture (i.e., earthen mounds) and large domestic village areas. The Shelby Mound site is one of the premier sites in a political community centered in the Greasy Creek basin and neighboring Big Cypress Creek basin (Figure 1).

The Shelby Mound site on Greasy Creek, the social and political center of a Greasy Creek political community, stretches for several hundred meters along Greasy Creek and a small tributary, with an earthen mound at the northern end of the village and a large cemetery at its southern end. Domestic village areas are between the mound and the cemetery and cover at least 10-15 acres (Perttula and Nelson 2004). The Titus phase earthen mound covered a burned structure at the base of the mound, and a second structure had been built that stood on the mound itself, and was then burned and capped with a final sandy fill intermixed with midden deposits. The arrangement of mound, domestic areas, and planned cemetery here is essentially duplicated at other important Titus phase communities in the Big Cypress Creek basin, although the village areas and the size of the cemetery at the Shelby Mound site are considerably larger than most of the others (Perttula 2012). Based on work at the site in 2002, the north levee area at the Shelby Mound site has thick midden deposits and evidence for several burned structures (Perttula and Nelson 2004), implying the existence of an intensive occupation here during the life of the community.

At the Shelby Mound site, the available documentation (see Mitchell 2000; Perttula and Nelson 2004) indicates that the many burial rows of interments in the large community cemetery had a roughly east-west orientation (Perttula 2012:Figure 13-7b), although four burials were more northeast-southwest in orientation. A total of 119 burial pits had been mapped by one of the diggers when the Shelby Mound site was being looted (see Perttula et al. 2012:Figure 4), and apparently more burials had been excavated in the cemetery besides those mapped, but the spatial patterning in this large community cemetery is clear.

Mitchell (2000) indicates that not all the burials at the Shelby Mound site were single, extended interments. Some apparently held multiple individuals, and several of the Caddo burials had been placed in deep and probable shaft tombs; signs of the looted shaft tombs were still visible at the cemetery in 2004 (Perttula and Nelson 2004). Notes on file at the Texas Archeological Research Laboratory at The University of Texas at Austin also indicate that there was a large concentration of daub in the area of the plotting of one such shaft tomb (see Perttula 2012:Figure 13-7b), and it is possible that this particular burial had been placed in the floor of a deliberately burned and wattle and daub-covered Caddo structure. This burial is also significant because in it were two $9 \mathrm{ft}$. long red cedar poles, a rare find indeed. A sample of one of the poles was 


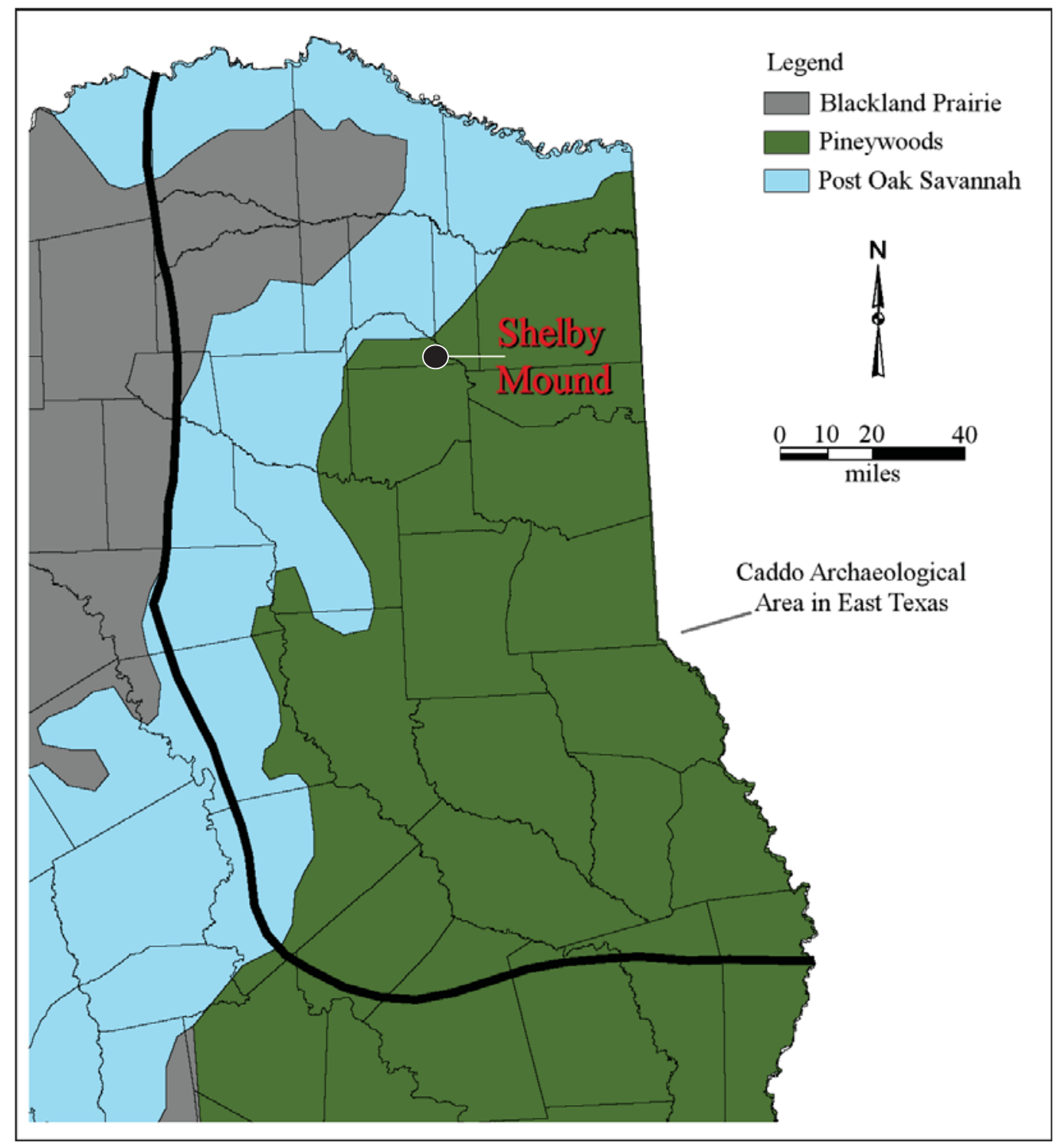

Figure 1. The location of the Shelby Mound site (41CP71) in the East Texas Pineywoods.

radiocarbon-dated, returning a 2 sigma (95\% probability) calibrated age range of A.D. 1430-1640, with a calibrated intercept of A.D. 1470 (Perttula 2009:20-21).

The cedar poles may be the preserved remnants of a wood litter upon which Burial 117 would have rested. One cannot think of a wood litter on a prehistoric Caddo site without considering the cedar pole burial litters in the Great Mortuary at the Spiro site (see Brown 1996:85-103), as these were among the most laden in mortuary contexts there with exotic marine shell artifacts, embossed copper plates, and other rare Southeastern ceremonial complex artifacts. While not as spectacular in that sense as the litter burials from Spiro, this litter burial at the Shelby Mound site was said to contain five whole ceramic vessels (two large brushed ollas, a Bailey Engraved bottle, a probable Wilder Engraved bottle, and a bowl), 22 arrow points, and many sherds from an uncertain number of other vessels (Mitchell 2000). The previously mentioned bowl was described by Mitchell (2000) as a unique tri-colored (red, yellow, and tan) bowl, which may be a Hatinu Engraved vessel, similar to those seen in vessel collections from the Hatchel (41BW3), Clements (41CS25) (Gonzalez et al. 2005:30 and Figure 4.5), and Foster (3LA27) (see Weinstein et al. 2003:Figures 106 and 107) sites in the Red River basin. 
Other notable burials at the Shelby Mound site had ceramic ear spools, rarely found in contexts other than those associated with the social elite, and at least three large $(20 \mathrm{~cm})$ black Big Fork chert bifacially-chipped blades (Galt bifaces) came from burials (Mitchell 2000). Finally, one burial (not identified by the burial no.) was accompanied by a very large cache of 120 arrow points, 117 of which were of the finely-chipped Talco type, along with celts, hammerstones, axes, and a probable heir-loomed bannerstone (Mitchell 2000). These kinds of funerary objects placed by the Caddo with the deceased at the Shelby Mound site are very much indicative of high-status Titus phase burials (see Perttula 2004:401; Thurmond 1990:235).

The social and cultural diversity that probably existed among Titus phase cultural groups is matched by the stylistic and functional diversity in Titus phase material culture, particularly in the manufacture and use of fine ware and utility ware ceramics, and the ceramic tradition is the surest grounds for evaluating attribution of archaeological components to the Titus phase. It is the character of their stylistically unique material culture (see Perttula 1998, 2000, 2005:401-410; Thurmond 1990), coupled with the development of distinctive mortuary rituals and social and religious practices centered on the widespread use of community cemeteries and mound ceremonialism as means to mark social identities (see Perttula and Nelson 1998; Perttula and Sherman 2009), that most readily sets these Caddo groups apart from their neighbors in East and Northeast Texas and in the Red River basin to the north and east.

This article discusses the analysis of the plain and decorated ceramic sherds (focusing on the latter) from the mound deposits at the Shelby Mound site in the Robert L. Turner collection. Because of the stratified nature of the mound deposits it is possible that temporal changes in the stylistic character of the utility wares and fine wares in use at the site can be detected, and full documentation of the assemblage at Shelby Mound will be key in stylistic comparisons of the ceramic traditions among contemporaneous Titus phase communities in the Big Cypress Creek basin (Perttula 2013:257-269) and the mid-Sabine River basin (Fields and Gadus 2012; Gadus 2013).

\section{MOUND DEPOSITS AND THEIR AGE}

The single mound at the Shelby Mound site is ca. $18.3 \mathrm{~m}$ in diameter and stands approximately $1.5 \mathrm{~m}$ in height. Between 1985-1988, Robert L. Turner and Ralph Nicholas excavated a single $10 \mathrm{x} 10 \mathrm{ft}$. (3.05 x $3.05 \mathrm{~m})$ unit (N200 W190) in the mound. The unit was divided into four $5 \times 5 \mathrm{ft}$. (1.52 x $1.52 \mathrm{~m})$ sub-units or squares, designated here Units A-D. These units were excavated in $0.5 \mathrm{ft}$. levels (ca. $15 \mathrm{~cm}$ thick), beginning with level 1, the uppermost surface level. Level 1 had a bottom elevation of $102.0 \mathrm{ft}$. Excavations reached the base of the mound in Level 11 (97.5-97.0 ft. in elevation), more than $1.5 \mathrm{~m}$ below its surface.

Based on available profiles and profile descriptions, the mound was apparently built with sediments and midden refuse collected from the adjoining village deposits and nearby stream deposits. The mound was built over a burned structure that would have stood on the pre-mound surface in level 11; this structure was marked by an arc of five post holes that originated at about $97.0 \mathrm{ft}$. bs. The burned structure was covered with about $1.0-1.5 \mathrm{ft}$. of sediments (represented by levels $9-11$ in the mound) early in the $15^{\text {th }}$ century (based on a 2 sigma calibrated age range of A.D. 1305-1460, with an A.D. 1420 intercept, on charred hickory nutshells in level 9), after which a second structure was erected on the mound itself. This structure was marked by an arc of circular post holes (see Perttula and Nelson 2004:Figure 15) at elevations of 98.9-98.5 ft. (level 8), as well as charcoal and ash, charcoal-stained soil, and oxidized sand. These deposits indicate the second structure was burned, probably deliberately; this burning may have taken place around A.D. 1490, based on a 2 sigma calibrated age range of A.D. 1425-1650, with an A.D. 1490 intercept, on charred plant remains from 98.85-98.5 ft. in the mound.

After the structure was burned, tan sand and grayish-blue clay sediments were placed over the burned house debris; these sediments are in levels 6 and 7 (100.0-99.5 ft. bs). The mound deposits above $100.0 \mathrm{ft}$. bs are comprised of sandy loams of varying colors, midden deposits with considerable numbers of ceramic sherds and some animal bones, along with mottled sand and clay, and individual basket loads of mound fill (Perttula and Nelson 2004:Figure 16). 


\section{CERAMIC ASSEMBLAGE}

The ceramic sherd assemblage from Units or Squares A, C, and D at the Shelby Mound site includes 4181 sherds (Table 1), including 2179 plain sherds and 2002 decorated sherds. The plain to decorated sherd ratio is 1.09 . There are another 593 decorated sherds from Unit $\mathrm{B}$, and these were previously discussed in Perttula and Nelson (2004:18-20 and Table 2). The sherds as an assemblage can be divided into four analytical units-levels 1-5 (upper mound fill), levels 6-7 (tan sand and clay mound fills), Level 8 (burned structural remains and associated debris), and levels 9-11 (mound fill above structural remains exposed at the base of Level 11) - based on the stratigraphy, nature of the sediments, and the occurrence of structural features in the mound, as discussed above. The largest samples of sherds in Units A, C, and D are in levels 1-5 and Level 8, and there are 1000 decorated sherds in levels 1-5; 282 in levels 6-7; 415 in Level 8; and 234 in levels 9-11 (Table 1). There are higher proportions of decorated sherds in the lower levels of the mound: 53\% in Level 8 and 59\% in levels 9-11, compared to 44\% in levels 1-5 and levels 6-7.

Table 1. Ceramic assemblage from Units A, C, and D in the Shelby Mound.

\begin{tabular}{|c|c|c|c|c|c|c|c|}
\hline \multirow[t]{2}{*}{ Level } & \multicolumn{2}{|c|}{ Unit A } & \multicolumn{2}{|c|}{ Unit C } & \multicolumn{2}{|c|}{ Unit D } & \multirow[t]{2}{*}{$\mathrm{N}$} \\
\hline & Plain & Decorated & Plain & Decorated & Plain & Decorated & \\
\hline 1 & 55 & 53 & 39 & 33 & 95 & 98 & 373 \\
\hline 2 & 87 & 58 & 38 & 38 & 122 & 127 & 470 \\
\hline 3 & 91 & 62 & 102 & 52 & 70 & 48 & 425 \\
\hline 4 & 53 & 58 & 106 & 59 & 112 & 88 & 476 \\
\hline 5 & 96 & 63 & 95 & 69 & 87 & 94 & 504 \\
\hline Subtotal & 382 & 294 & 380 & 251 & 486 & 455 & 2248 \\
\hline 6 & 68 & 50 & 95 & 60 & 62 & 53 & 388 \\
\hline 7 & 33 & 45 & 45 & 16 & 51 & 58 & 248 \\
\hline Subtotal & 101 & 95 & 140 & 76 & 113 & 111 & 636 \\
\hline 8 & 118 & 113 & 76 & 87 & 174 & 215 & 783 \\
\hline 9 & 30 & 45 & - & - & 41 & 49 & 165 \\
\hline 10 & 16 & 24 & - & - & 53 & 70 & 163 \\
\hline 11 & 5 & 14 & - & - & 15 & 32 & 66 \\
\hline Subtotal & 51 & 83 & - & - & 109 & 151 & 394 \\
\hline Misc.* & 35 & 53 & - & - & 14 & 19 & 121 \\
\hline Totals & 687 & 638 & 596 & 413 & 896 & 951 & 4181 \\
\hline
\end{tabular}

*sherds from features (in the case of Unit D) that likely originated in level 8, or from portions of multiple levels (Unit A)

There is a considerable difference in the density of sherds in the four analytical units in the mound excavations. The density of sherds is 422 sherds per $\mathrm{m}^{3}$ in levels $1-5 ; 303$ sherds per $\mathrm{m}^{3}$ in levels $6-7$; a very substantial 746 sherds per $\mathrm{m}^{3}$ in level 8; and 285 sherds per $\mathrm{m}^{3}$ in levels 9-11.

There are 261 rim sherds in the assemblage: $27 \%$ are from plain wares, $32 \%$ are from fine ware vessels, and the remaining $41 \%$ are from utility wares. The relative proportion of the three wares as adduced from the percentages of rim sherds may be skewed because some of the small plain rims may be from one or the other decorated ware that is not decorated right at the rim, but in decorated panels that only begin at 
the mid-rim. In any case, it is clear that all three wares are common and roughly equally distributed in the mound deposits at the Shelby Mound site.

The ceramic assemblage is almost exclusively grog, grog-bone-tempered, or bone-tempered (Perttula and Nelson 2004:21). A prior analysis of a sample of plain sherds from the village area at the site indicated that approximately $79 \%$ of the sherds were grog-tempered, $16 \%$ were grog and bone-tempered, and $4 \%$ were bone-tempered. The remaining $0.5 \%$ of the plain sherds were shell-tempered; these are from non-locally made Caddo ceramic vessels, likely with source areas to Caddo groups in the mid-Red River (McCurtain phase) or the Great Bend area (Belcher phase) of the Red River (see Perttula et al. 2012).

\section{Plain Sherds}

Plain rim, body, and base sherds are common throughout the mound deposits (Table 2). These sherds are from bowls (simple bowls and carinated bowls) and jars. Rims comprise only about $3 \%$ of the plain sherds, and base sherds another $4.5 \%$.

Table 2. Plain sherds from Units A, C-D.

\begin{tabular}{|c|c|c|c|c|c|}
\hline Level & $\operatorname{Rim}$ & Body & Shell-tempered, Body & Base & $\mathrm{N}$ \\
\hline 1 & 8 & 170 & 2 & 9 & 189 \\
\hline 2 & 9 & 230 & 1 & 7 & 247 \\
\hline 3 & 6 & 245 & 2 & 10 & 263 \\
\hline 4 & 7 & 250 & 3 & 11 & 271 \\
\hline 5 & 4 & 258 & 2 & 14 & 278 \\
\hline Subtotal & 34 & 1153 & 10 & 51 & 1248 \\
\hline 6 & 8 & 200 & - & 17 & 225 \\
\hline 7 & 6 & 116 & - & 7 & 129 \\
\hline Subtotal & 14 & 316 & - & 24 & 354 \\
\hline 8 & 14 & 338 & - & 16 & 368 \\
\hline 9 & 3 & 64 & - & 4 & 71 \\
\hline 10 & 2 & 66 & - & 1 & 69 \\
\hline 11 & - & 19 & - & 1 & 20 \\
\hline Subtotal & 5 & 149 & - & 6 & 160 \\
\hline Misc. & 4 & 43 & - & 2 & 49 \\
\hline Totals & 71 & 1999 & 10 & 99 & 2179 \\
\hline
\end{tabular}

There are a few shell-tempered body sherds in the plain sherd assemblage from the Shelby Mound site, amounting to $0.5 \%$ of the plain wares (see Table 2). All of the plain shell-tempered sherds occur in the uppermost mound/midden deposits in levels 1-5. 


\section{Decorated Sherds}

Units A-D in the mound have 2591 decorated sherds (Table 3). Approximately $24.0 \%$ of these sherds are from fine wares - principally sherds from engraved vessels - and the remainder are from utility ware jars. Most of these have brushed, brushed-incised, incised, and punctated decorative elements on the rim and/or the vessel body.

In terms of broad changes in the proportion of decorative methods in the different stratigraphic deposits in the mound, there are a few notable differences worth mentioning. First, the proportion of brushed utility ware sherds decreases from 52.5-53.6\% in Level 8 and levels 9-11 to $48.6 \%$ in levels 6-7 and $45.1 \%$ in levels 1-5 (see Table 3). There are corresponding increases in the relative proportions of incised utility wares in the upper mound deposits (12.0-13.4\%) compared to the lower mound deposits (8.7-10.3\%), as there also are in the proportions of punctated utility wares (4.2-5.8\% in the upper mound levels and only $2.6 \%$ in the lower mound levels, see Table 3 ). The few trailed (Keno Trailed) fine ware sherds are found primarily in levels 1-5 (see Table 3). Brushed-appliqued sherds, although rare, are also most common in the upper mound deposits.

In more specific terms, fine wares are abundant in all levels of the mound, comprising between 22.4$24.8 \%$ of the decorated sherds by analytical unit (see Table 3 ); red-slipped sherds are slightly more abundant in levels 1-5 and levels 6-7 than they are in the lower mound deposits. Neck banded sherds are present in very low proportions throughout the various mound deposits, as are most of the other less well represented utility wares (see Table 3), including sherds with brushed-punctated, appliqued, incised-punctated, brushedappliqued, incised-appliqued, and brushed-incised-punctated decorative elements.

An assemblage of 69 vessels from the Shelby site is in the Margaret Hinton collection (Perttula et al. 2012:137-206). There is one plain bottle in the assemblage, and all the others are decorated on the rim and/ or the body. Utility ware jars include Bullard Brushed ( $n=3)$, Cass Appliqued ( $n=1)$, Harleton Appliqued $(n=2)$, Karnack Brushed-Incised ( $n=1)$, La Rue Neck Banded ( $n=4)$, Mockingbird Punctated $(n=3)$, Pease Brushed-Incised $(n=2)$, and horizontal incised $(n=1)$, brushed-incised-punctated $(n=1)$, incised-punctated $(\mathrm{n}=1)$, incised-appliqued $(\mathrm{n}=1)$, punctated $(\mathrm{n}=1)$, and punctated-appliqued jars $(\mathrm{n}=1)$. The fine wares include Bailey Engraved ( $\mathrm{n}=1)$, Ripley Engraved, cf. var. Carpenter $(\mathrm{n}=2)$, Ripley Engraved, var. Cash $(\mathrm{n}=1)$, Ripley Engraved, var. Galt ( $\mathrm{n}=3)$, Ripley Engraved, cf. var. Gandy $(\mathrm{n}=2)$, Ripley Engraved, var. McKinney $(\mathrm{n}=8)$, Ripley Engraved, var. Pilgrims $(\mathrm{n}=1)$, Ripley Engraved, var. Ripley $(\mathrm{n}=3)$, Ripley Engraved, var. Williams $(\mathrm{n}=3)$, Ripley Engraved, var. unspecified $(\mathrm{n}=9)$, Simms Engraved $(\mathrm{n}=2)$, Taylor Engraved $(\mathrm{n}=1)$, Turner Engraved, var. Turner $(\mathrm{n}=1)$, Turner Engraved, var. unspecified $(\mathrm{n}=2)$, Wilder Engraved, var. Wilder $(\mathrm{n}=3)$, Wilder Engraved, var. unspecified $(\mathrm{n}=1)$, an engraved-punctated carinated bowl, and unidentified engraved carinated bowls $(n=2)$ and compound bowls $(n=1)$.

Most of these same defined ceramic types and varieties, as well as certain distinctive decorative elements in the fine wares, can be identified in the sherd assemblage from the mound deposits. Specifically:

- in levels 1-5: Bullard Brushed, Cass Appliqued, Harleton Appliqued, La Rue Neck Banded, Maydelle Incised, Mockingbird Punctated, Pease Brushed-Incised, Bailey Engraved, Hodges Engraved, Keno Trailed, Ripley Engraved, var. Gandy, Ripley Engraved, var. McKinney, Ripley Engraved, var. Ripley, Ripley Engraved, var. unspecified, Taylor Engraved, Turner Engraved, var. unspecified, engraved-punctated sherds, a fabric-impressed and red slipped sherd, and engraved SZ elements (see Fields and Gadus 2012);

- levels 6-7: Bullard Brushed, Harleton Appliqued, Maydelle Incised, Mockingbird Punctated, Pease Brushed-Incised, possible Avery Engraved, Ripley Engraved, var. Carpenter, Ripley Engraved, var. Gandy, and engraved SZ elements; 


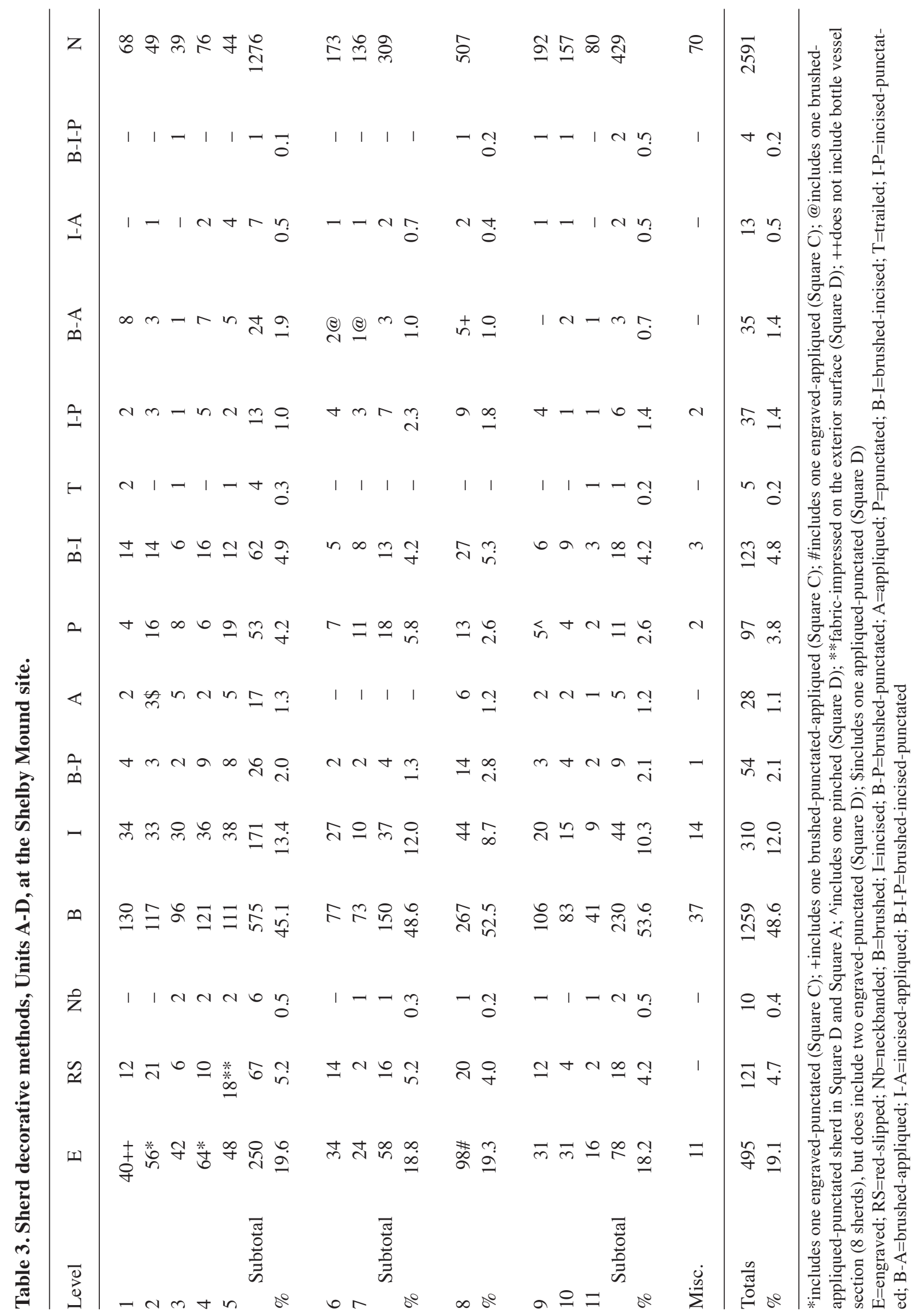


- level 8: Bullard Brushed, Harleton Appliqued, Maydelle Incised, Pease Brushed-Incised, Ripley Engraved, var. unspecified, and engraved SZ elements;

- and in levels 9-11: Bullard Brushed, Mockingbird Punctated, Pease Brushed-Incised, Ripley Engraved, var. Reed, and Ripley Engraved, var. unspecified.

As can be seen, certain ceramic types occur throughout the mound deposits: Bullard Brushed, Pease Brushed-Incised, and Ripley Engraved, var. unspecified. The occurrence of a few sherds from Hodges Engraved, Keno Trailed, and Taylor Engraved vessels, as well as a number of sherds from Ripley Engraved, var. McKinney vessels in level 1-5 in the mound suggests this deposit post-dates ca. A.D. 1550-1600, in the late Titus phase (ca. A.D. 1550-1680). Much of the community cemetery was used at this time, along with significant portions of the village area, especially Area I/northern levee not far from the mound (Perttula and Nelson 2004:41 and Figure 1). A 2 sigma calibrated age range of A.D. 1512-1665, with a median calibrated age of A.D. 1572, has been obtained on residue adhering to the walls of an incised-appliqued jar from the cemetery (Perttula and Selden 2013). The ceramics from levels 6-11 in the mound probably date to the early Titus phase (ca. A.D. 1430-1550), based on calibrated intercepts of A.D. 1420 and A.D. 1490 from levels 8 and 9 , as well as the range of decorated utility ware and fine ware sherds found in these deposits. The village areas at the Shelby Mound site were also occupied during this period of time, and the community cemetery was also in use.

\section{Utility Ware Sherds}

In Units A, C, and D in the mound deposits at the Shelby Mound site, approximately $76 \%$ of the decorated sherds are from utility ware jars (Table 4). Including both rim and body sherds, $72.9 \%$ of these sherds have brushed decorative elements, either as the sole decoration $(60.7 \%)$, or in lesser combinations with either appliqued, appliqued-incised, appliqued-punctated, incised, incised-punctated, or punctated elements. Among just the rim sherds, however, the most common utility wares have incised (33\%), punctated (23\%), brushed (21\%), brushed-punctated (8\%), and incised-punctated (8\%) decorative elements (Table 4). Those decorative methods listed in Table 4 that do not have rim sherds likely indicate the fact that some particular elements (i.e., appliqued) or combination of elements (i.e., brushed-appliqued) were confined to the vessel bodies, while the other decorative elements were to be found on both the rim and/or the body; this is a common Titus phase decorative practice (Perttula 2014).

\section{Appliqued}

The appliqued body sherds feature nodes, fillets, and ridges (Table 5) on the bodies of utility ware jars (Figure 2a-b, d). The sherds with regular and/or widely-spaced parallel appliqued ridges are likely from Cass Appliqued jars (see Suhm and Jelks 1962:Plate 13), and the others may be from McKinney Plain jars (Suhm and Jelks 1962:Plate 49).

\section{Appliqued-punctated}

There is only one sherd in the Shelby Mound ceramic assemblage with an appliqued-punctated decoration. This is a body sherd (Unit D, level 2) from a jar with a straight appliqued ridge and an adjacent row of tool punctations. 
Table 4. Utility ware sherd assemblage from all levels in Units A, C-D.

\begin{tabular}{lrrrr}
\hline Decorative method & Rim & Body & N & $\%$ \\
\hline Appliqued & - & 24 & 24 & 1.6 \\
Appliqued-punctated & - & 1 & 1 & 0.1 \\
Brushed & 23 & 900 & 923 & 60.7 \\
Brushed-appliqued & - & 18 & 18 & 1.2 \\
Brushed-appliqued-incised & - & 1 & 1 & 0.1 \\
Brushed-appliqued-punctated & - & 3 & 3 & 0.2 \\
Brushed-incised & 1 & 121 & 122 & 8.0 \\
Brushed-incised-punctated & 2 & 2 & 4 & 2.3 \\
Brushed-punctated & 11 & 25 & 36 & 17.7 \\
& 35 & 234 & 269 & 0.8 \\
Incised & - & 12 & 12 & 2.2 \\
Incised-appliqued & 9 & 24 & 33 & 0.3 \\
Incised-punctated & & & & 0.1 \\
Neck Banded & 1 & 1 & 4 & 0.1 \\
Neck Banded-punctated & - & 1 & 1 & 4.7 \\
Pinched & - & 47 & 72 & 100.0 \\
Punctated & 25 & 1417 & 1524 & \\
\hline Totals & 107 & & & 1 \\
\hline
\end{tabular}

Table 5. Decorative elements on appliqued body sherds.

\begin{tabular}{lcc}
\hline Decorative element & $\mathrm{N}$ & $\%$ \\
\hline appliqued node & 2 & 8.3 \\
row of appliqued nodes & 1 & 4.2 \\
& & 8.3 \\
curvilinear appliqued fillet & 2 & 20.8 \\
straight appliqued fillet & 5 & 4.2 \\
straight appliqued fillet and appliqued node & 1 & 12.5 \\
parallel appliqued ridges & 3 & 41.7 \\
straight appliqued ridge & 10 & 100.0 \\
\hline Totals & 24 & \\
\hline
\end{tabular}




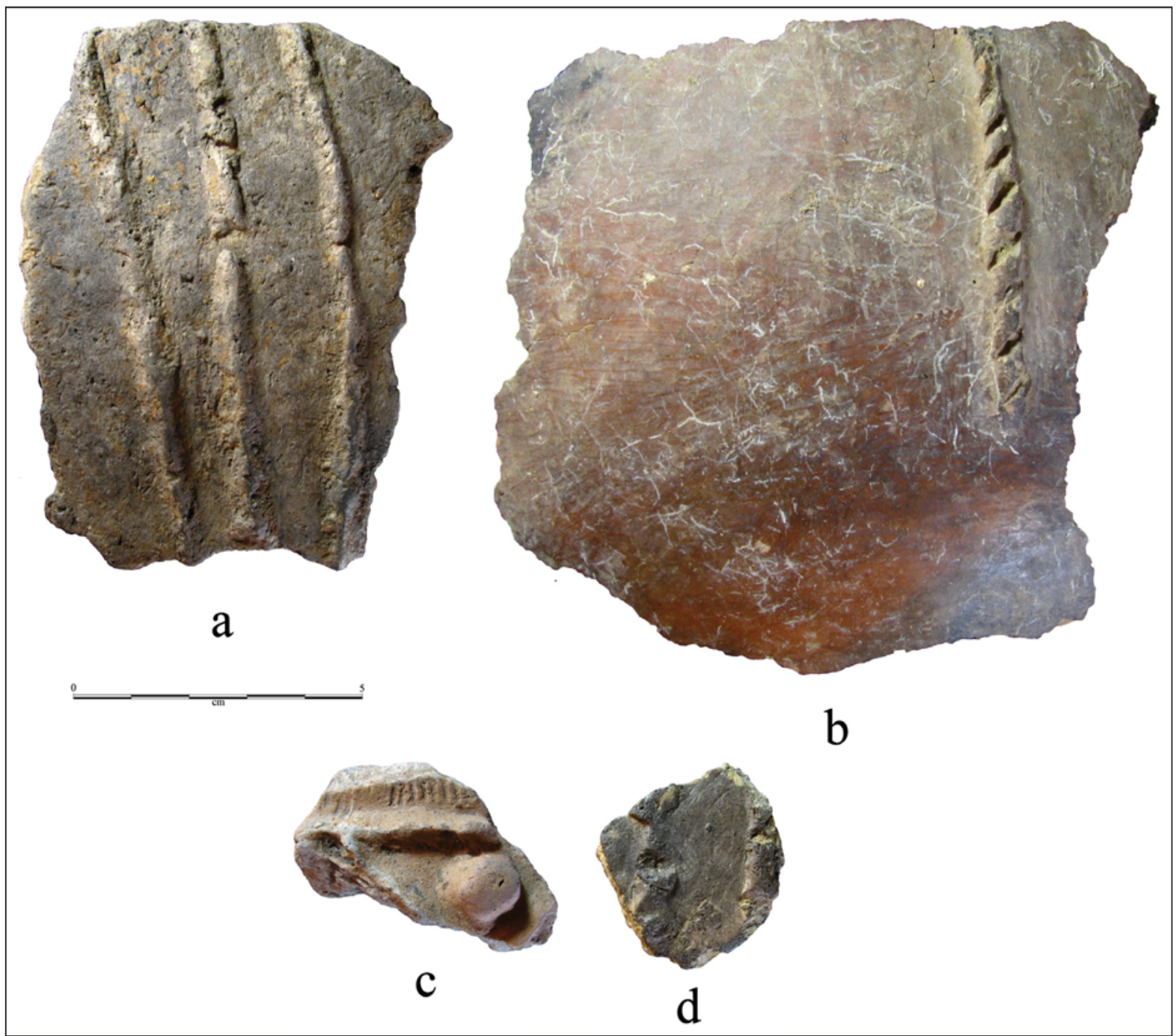

Figure 2. Appliqued and brushed-appliqued body sherds: a, appliqued, Unit D, level 5; b, appliqued, Unit D, level 8; c, brushed-appliqued, Unit D, level 5; d, appliqued, Unit A, level 3.

Table 6. Decorative elements on brushed rim sherds.

\begin{tabular}{lrr}
\hline Decorative element & $\mathrm{N}$ & $\%$ \\
\hline Diagonal brushed & 3 & 13.0 \\
Horizontal brushed & 19 & 82.6 \\
Vertical brushed & 1 & 4.3 \\
\hline Totals & 23 & 100.0 \\
\hline
\end{tabular}




\section{Brushed}

Sherds from brushed vessels are abundant in the mound deposits at the Shelby Mound, comprising 60.7\% of the decorated utility wares in Units A, C, and D (see Table 4). The rims of brushed jars primarily have horizontal brushing marks (Table 6 and Figure 3a), but a few have diagonal and vertical brushing marks. These are all most likely from Bullard Brushed jars (see Suhm and Jelks 1962:21), although Harleton Appliqued rims are also sometimes brushed horizontally (Suhm and Jelks 1962:65).

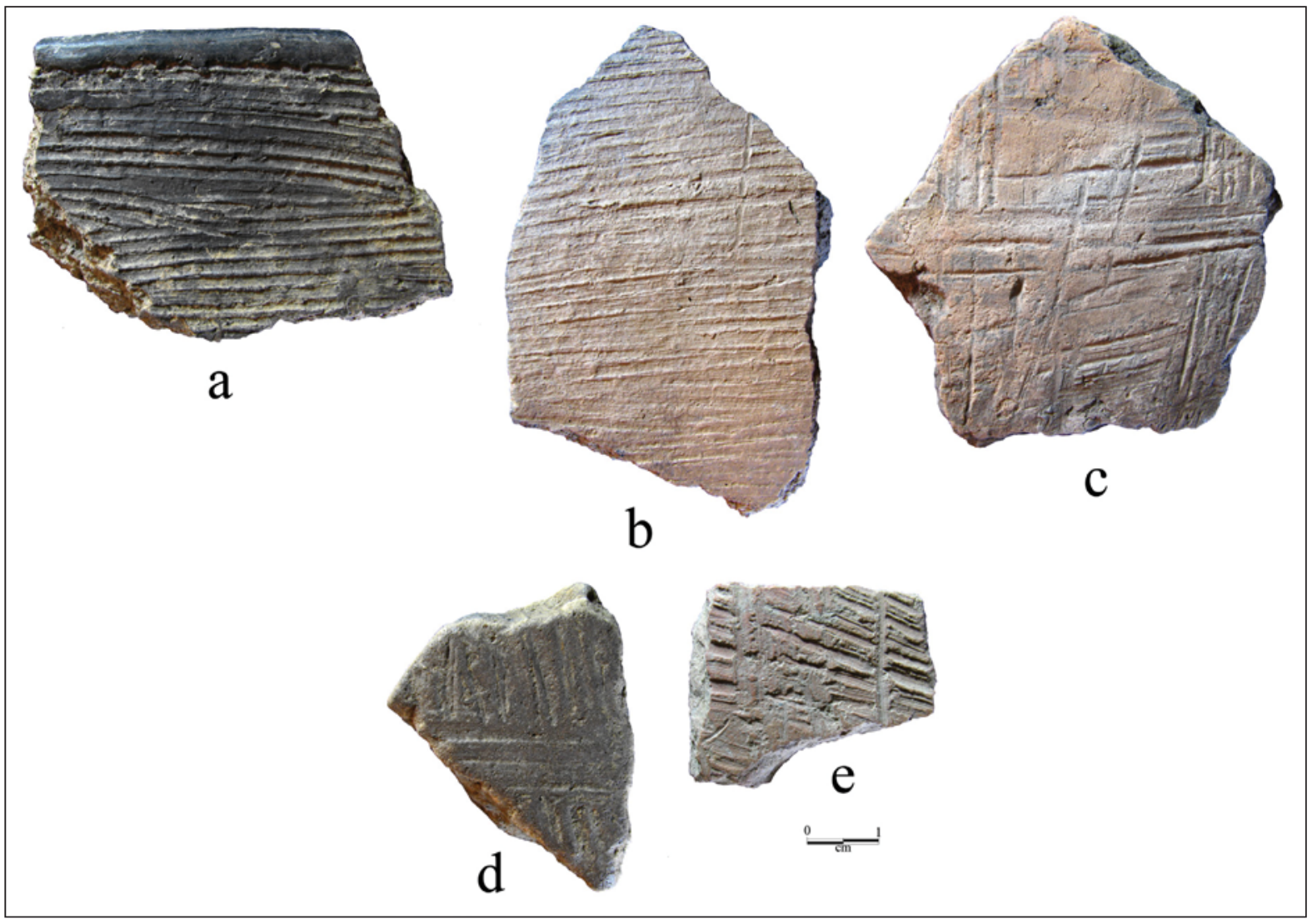

Figure 3. Brushed and brushed-incised rim and body sherds: a, brushed rim, Unit D, level 8; b, brushed body, Unit D, level 8; c, brushed-incised, Unit D, level 1; d, brushed-incised, Unit D, level 1; e, brushed-incised, Unit A, level 9/10.

Body sherds with brushed decorations almost exclusively have parallel brushing marks (Table 7 and Figure $3 b$ ). Although the orientation of these sherds is not known, it is likely that the brushing actually runs vertically on jar bodies. Only $3.2 \%$ of the brushed body sherds do not have parallel/vertical brushing marks.

\section{Brushed-appliqued}

Brushed-appliqued body sherds have appliqued fillets and appliqued ridges that probably were vertically oriented on the body of jars. These fillets and ridges created panels filled with parallel/vertical brushing marks (Table 8), and these sherds are likely from Pease Brushed-Incised vessels (Suhm and Jelks 1962:119). The one body sherd with a curvilinear appliqued fillet-parallel brushed decoration (see Figure 2c) may be from a Harleton Appliqued jar (Suhm and Jelks 1962:65). 
Table 7. Decorative elements on brushed body sherds.

\begin{tabular}{lrr}
\hline Decorative element & N & $\%$ \\
\hline diagonal brushed & 1 & 0.1 \\
opposed brushed & 12 & 1.3 \\
overlapping brushed & 16 & 1.8 \\
parallel brushed & 871 & 96.8 \\
\hline Totals & 900 & 100.0 \\
\hline
\end{tabular}

Table 8. Decorative elements on brushed-appliqued body sherds.

\begin{tabular}{lcr}
\hline Decorative element & N & $\%$ \\
\hline curvilinear appliqued fillet and parallel brushed & 1 & 5.6 \\
straight appliqued fillet and parallel brushed & 14 & 77.8 \\
& 1 & 5.6 \\
parallel appliqued ridges and parallel brushed & 2 & 11.1 \\
straight appliqued ridge and parallel brushed & 18 & 100.0 \\
\hline Totals & & \\
\hline
\end{tabular}

\section{Brushed-appliqued-incised}

This body sherd (Unit D, level 4) is from a Harleton Appliqued jar. It has straight and V-shaped appliqued fillets with parallel incised lines between them, and parallel brushing marks within the V-shaped fillet (Figure 4f). Another body sherd has a straight appliqued fillet dividing a panel filled with parallel brushed and overlapping incised lines (Figure 4c).

\section{Brushed-appliqued-punctated}

One of the brushed-appliqued-punctated body sherds (Unit C, level 8) is from a Harleton Appliqued jar. It has curvilinear appliqued fillets and adjacent bands of curvilinear brushing, with single rows of tool punctates between the fillets (see Figure 4a). Another sherd (Unit D, level 6) has a straight appliqued fillet, parallel brushing marks, and a vertical row of tool punctates (see Figure 4b). The last of these sherds (Unit A, level 7) has a straight appliqued ridge, adjacent areas with horizontal brushing marks, and a row of tool punctations pushed through the brushing.

\section{Brushed-incised}

Brushed-incised decorative elements are a rather common utility ware in the Shelby Mound (see Table 4), comprising $8 \%$ of the utility ware sherds in Units A, C, and D. Most of these sherds have parallel brushing marks and intermixed straight incised lines, but $10 \%$ of the sherds have incised lines of various orientations that overlie and cut through the brushing elements (see Figure $3 \mathrm{c}-\mathrm{e}$ ). 


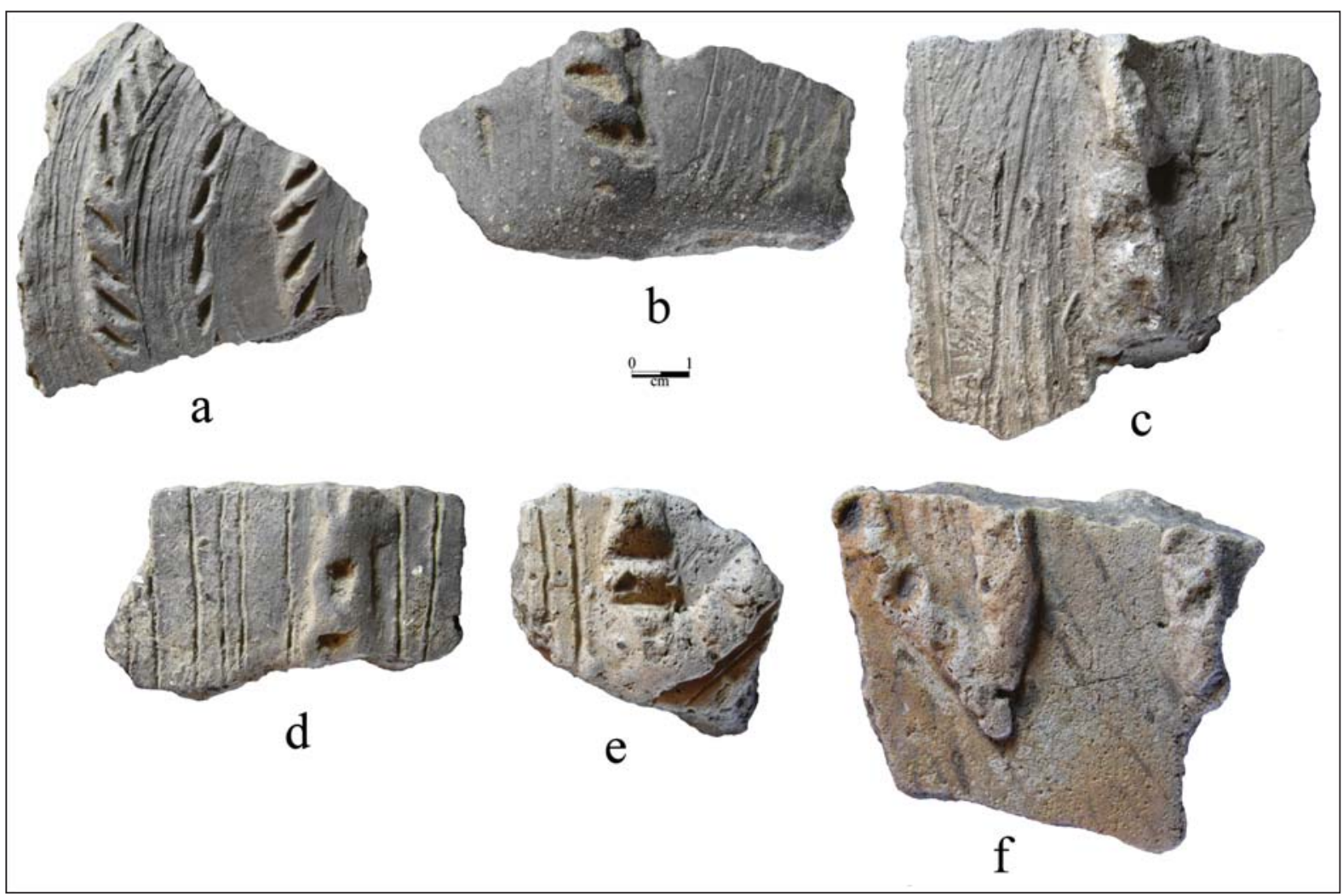

Figure 4. Brushed-appliqued-punctated, brushed-appliqued-incised, and incised-appliqued body sherds: a, Unit C, level 8; b, Unit D, level 6; c, Unit C, level 3; d, Unit C, level 4; e, Unit C, level 6; f, Unit D, level 4.

Table 9. Decorative elements on brushed-incised body sherds.

\begin{tabular}{lcc}
\hline Decorative element & $\mathrm{N}$ & $\%$ \\
\hline horizontal incised lines-diagonal brushed & 1 & 0.8 \\
horizontal incised-vertical brushed-incised & 1 & 0.8 \\
straight incised lines-opposed brushed & 1 & 0.8 \\
horizontal brushed-diagonal incised lines & 1 & 0.8 \\
horizontal brushed-vertical incised lines & 1 & 0.8 \\
& & 85.1 \\
parallel brushed-incised & 103 & 0.8 \\
vertical brushed-incised & 1 & 0.8 \\
parallel brushed-overlying cross-hatched incised lines & 1 & 0.8 \\
parallel brushed-overlying opposed incised lines & 1 & 8.3 \\
parallel brushed-overlying parallel incised lines & 10 & 100.0 \\
\hline Totals & 121 & \\
\hline
\end{tabular}


The remainder of the brushed-incised sherds (4.0\%) have distinct incised or brushed decorative elements on the lower rim of jars and the opposite incised or brushed decorative elements on the body. Thus, three lower rim sherds have incised elements while the vessel body has diagonal, vertical, or opposed brushing marks, while two others have horizontal brushed lower rims and diagonal or vertical incised lines on the vessel body (see Table 9).

The one brushed-incised rim sherd (Unit A, level 7, from the clay fill zone over the burned structure) has horizontal brushing marks and incised lines on the vessel rim.

\section{Brushed-incised-punctated}

One (Unit C, level 3) of the two rims in this decorative category has horizontal brushed-incised marks and lines on the rim, with a horizontal row of tool punctations pushed through the brushed-incised decorative element. The other (Unit A, level 9) has a tool punctated row below the lip and horizontal brushed-incised marks and lines on the rim (Figure 5b). A body sherd (Unit D, level 8) has a zone of parallel brushing marks outlined by rows of tool punctations and these elements are opposed to a single straight incised line, and another has a row of tool punctates at the rim-body juncture and horizontal brushed-incised marks and lines on the vessel body (Figure 5d).

\section{Brushed-punctated}

Utility ware rims with brushed-punctated decorations can be divided into two categories: (1) rims with a row of tool punctations at or near the lip, and brushing on the remainder of the rim (63.7\% of the brushedpunctated rims) (see Figure 5a, c), and (2) brushed rims with a row of tool punctations pushed through the brushing (36.4\% of the brushed-punctated rims) (Table 10). These rims are likely from Bullard Brushed and Pease Brushed-Incised jars (see Suhm and Jelks 1962:21, 119).

Most of the brushed-punctated body sherds (64\%) have a row of tool punctates pushed through brushing marks that are oriented in several directions (Table 11). One lower rim-body sherd has vertical brushing marks on the rim, a tool punctated row at the rim-body juncture, and a horizontal brushed body; a row of tool punctates is pushed through the brushing marks (see Figure 5e).

The remainder of the brushed-punctated body sherds have areas of brushing paralleled by a row or rows of tool punctations that are oriented in the same direction as the brushing (see Table 11). Most of these sherds have horizontal brushing marks above a row of tool punctates.

\section{Incised}

Almost $18 \%$ of the utility wares in the Shelby Mound site mound deposits have incised decorative elements. The principal decorative element on the rim sherds is sets of diagonal lines on Maydelle Incised jars that are pitched in one direction around the vessel rim (Table 12 and Figure 6c). Other important incised decorative elements include horizontal lines around the rim as well as rims with opposed diagonal lines; the latter are also from Maydelle Incised jars (Figure 6a). One rim has a diagonal incised zone filled with vertical hatched lines (Figure 6b). 


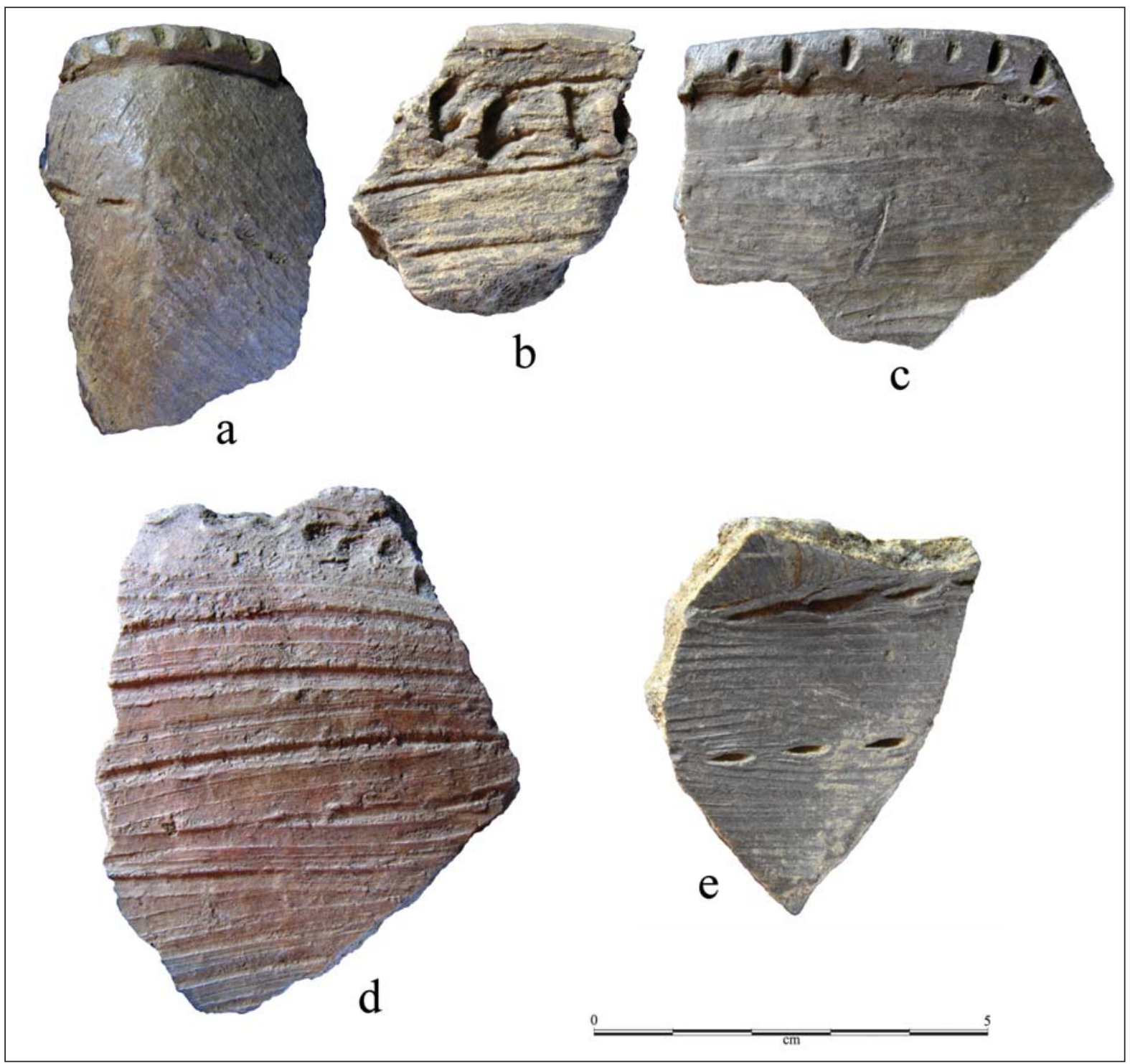

Figure 5. Brushed-incised-punctated and brushed-punctated rim and body sherds: a, brushed-punctated, Unit A, level 6; b, brushed-incised-punctated, Unit C, level 3; c, brushed-punctated, Unit D, level 2; d, brushedincised-punctated, Unit D, level 10; e, Unit C, level 5.

Table 10. Decorative elements on brushed-punctated rim sherds.

\begin{tabular}{lrr}
\hline Decorative element & N & $\%$ \\
\hline Horizontal brushed on rim-tool punctated row below lip & 5 & 45.5 \\
Horizontal brushed on rim-tool punctated row at lip & 1 & 9.1 \\
Tool punctated row above vertical brushing & 1 & 9.1 \\
Horizontal brushed-tool punctated row through brushing & 3 & 27.3 \\
$\begin{array}{l}\text { Opposed brushed with tool punctated row through } \\
\text { brushing and in a row below the lip }\end{array}$ & 1 & 9.1 \\
\hline Totals & 11 & 100.0 \\
\hline
\end{tabular}


Table 11. Decorative elements on brushed-punctated body sherds.

\begin{tabular}{|c|c|c|}
\hline Decorative element & $\mathrm{N}$ & $\%$ \\
\hline opposed brushed-tool punctated row through brushing & 2 & 8.0 \\
\hline parallel brushed-tool punctated row through brushing & 13 & 52.0 \\
\hline $\begin{array}{l}\text { vertical brushed (lower rim) with vertical punctates } \\
\text { through brushing; tool punctated row at rim-body } \\
\text { juncture; horizontal brushed (body) with tool } \\
\text { punctated row through brushing }\end{array}$ & 1 & 4.0 \\
\hline horizontal brushed-tool punctated row & 4 & 16.0 \\
\hline $\begin{array}{l}\text { horizontal brushed (lower rim)-tool punctated row } \\
\text { at rim-body-juncture-vertical brushed (body) }\end{array}$ & 1 & 4.0 \\
\hline $\begin{array}{l}\text { opposed diagonal brushed and opposed diagonal } \\
\text { tool punctated rows }\end{array}$ & 1 & 4.0 \\
\hline tool punctated row above vertical brushed & 3 & 12.0 \\
\hline Totals & 25 & 100.0 \\
\hline
\end{tabular}

Table 12. Decorative elements on incised rim sherds.

\begin{tabular}{lrr}
\hline Decorative element & N & $\%$ \\
\hline Cross-hatched lines & 1 & 2.9 \\
Diagonal lines & 24 & 68.6 \\
Hatched incised zone & 1 & 2.9 \\
Horizontal lines/horizontal line below the lip & 4 & 11.4 \\
Incised chevrons & 1 & 2.9 \\
Opposed diagonal lines & 2 & 5.7 \\
Opposed diagonal lines with nested hatched triangles & 1 & 2.9 \\
Vertical incised lines & 1 & 2.9 \\
\hline Totals & 35 & 200.0 \\
\hline
\end{tabular}

Body sherds with incised lines have simple geometric elements: straight, horizontal, diagonal, vertical, and diagonal opposed lines (see Figure 6d-e and Table 13). Only two sherds have cross-hatched incised lines and another two body sherds have sets of curvilinear lines.

\section{Incised-appliqued}

The few body sherds with incised-appliqued decorative elements have fillets (41.7\%), appliqued ridges $(41.7 \%)$, and noded (16.6\%) elements with adjacent sets of incised lines oriented in various directions relative to the position to the appliqued elements (Table 14; see Figure 4d-e). At least one sherd is from the body of an Harleton Appliqued jar, where the diagonal opposed incised lines filled the spaces between appliqued ridges; an appliqued node appears to sit at the center of the incised-appliqued decorative element (see Figure 6f). 


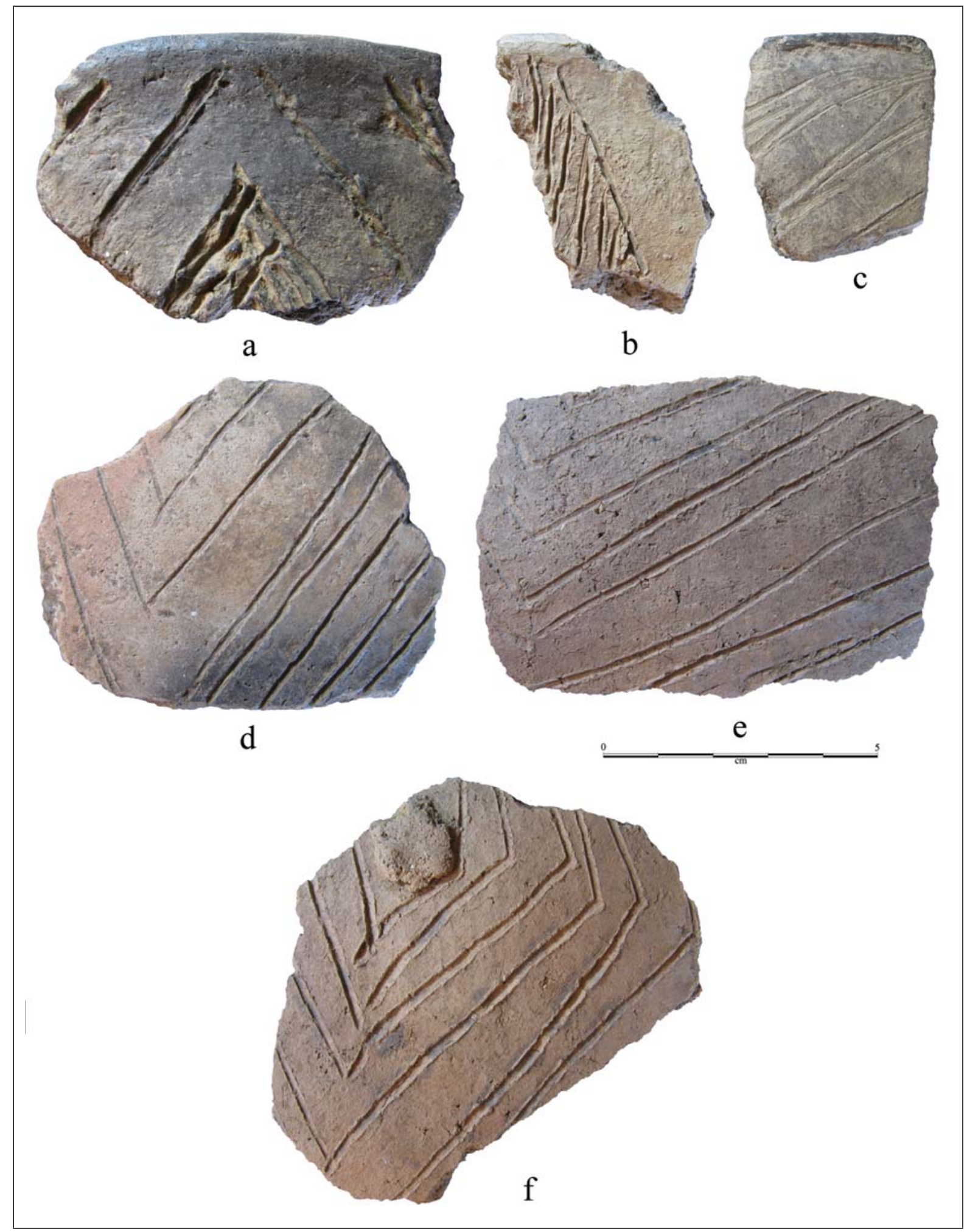

Figure 6. Incised rim and body sherds: a, Unit A, level 1; b, Unit D, level 9; c, Unit D, level 2; d, Unit C, level 2; e, Unit A, level 5; f, Unit A, level 5. 
Table 13. Decorative elements on incised body sherds.

\begin{tabular}{lrr}
\hline Decorative element & $\mathrm{N}$ & $\%$ \\
\hline cross-hatched lines & 2 & 0.9 \\
curvilinear lines & 2 & 0.9 \\
diagonal lines & 4 & 1.7 \\
horizontal and diagonal lines & 1 & 0.4 \\
opposed lines & 25 & 10.7 \\
opposed diagonal lines (chevron) & 5 & 2.1 \\
parallel lines & 158 & 67.5 \\
straight line & 35 & 15.0 \\
vertical lines & 1 & 0.4 \\
vertical and opposed diagonal lines & 1 & 0.4 \\
\hline Totals & 234 & 100.0 \\
\hline
\end{tabular}

Table 14. Decorative elements on incised-appliqued body sherds.

\begin{tabular}{lcc}
\hline Decorative element & $\mathrm{N}$ & $\%$ \\
\hline diagonal incised lines and straight appliqued fillet & 2 & 16.7 \\
parallel incised lines and straight appliqued fillet & 2 & 16.7 \\
$\begin{array}{l}\text { V-shaped appliqued fillet and diagonal opposed } \\
\text { incised lines }\end{array}$ & 1 & 8.3 \\
diagonal incised lines and straight appliqued ridge & 1 & 8.3 \\
parallel incised lines and straight appliqued ridge & 1 & 8.3 \\
V-shaped appliqued ridge, appliqued node, and & 1 & 8.3 \\
$\quad$ diagonal incised lines & & 16.7 \\
straight and opposed incised lines and straight & 2 & 8.3 \\
appliqued ridge & & 8.3 \\
diagonal opposed incised lines and appliqued node & 1 & 100.0 \\
\hline parallel incised lines and appliqued node & 1 & \\
\hline Totals & 12 & \\
\hline
\end{tabular}

\section{Incised-punctated}

The incised-punctated rim sherds in the mound deposits comprise several distinct combinations of incised lines and tool punctations (Table 15). The majority of the rims have a tool punctated row below the jar lip, and horizontal, diagonal, or vertical incised lines on the rim itself (Figure 7b-c); these may be from Harleton Appliqued, Maydelle Incised, or Pease Brushed-Incised vessels. One Maydelle Incised rim has incised triangles filled with tool punctations. Other rims have distinctive rim peaks with vertical punctated elements nestled in the rim peak, above sets of horizontal incised lines (Figure 8a-d).

The other incised-punctated rim sherds have multiple rows of incised lines and punctations, either with the punctations between an incised band, or in alternating sets on the rim itself (see Figure 7a). 
Table 15. Decorative elements on incised-punctated rim sherds.

\begin{tabular}{llc}
\hline Decorative element & $\mathrm{N}$ & $\%$ \\
\hline Banded incised lines-tool punctations between lines & 1 & 11.1 \\
Tool punctated rows and horizontal incised lines & 1 & 11.1 \\
Incised triangles filled with tool punctations & 2 & 22.2 \\
$\begin{array}{l}\text { Tool punctated row below lip-horizontal incised lines } \\
\text { Tool punctated row below lip-horizontal and diagonal } \\
\text { incised lines on the rim }\end{array}$ & 2 & 22.2 \\
$\begin{array}{l}\text { Tool punctated row below lip-vertical incised lines } \\
\text { Totals }\end{array}$ & 1 & 11.1 \\
\hline
\end{tabular}

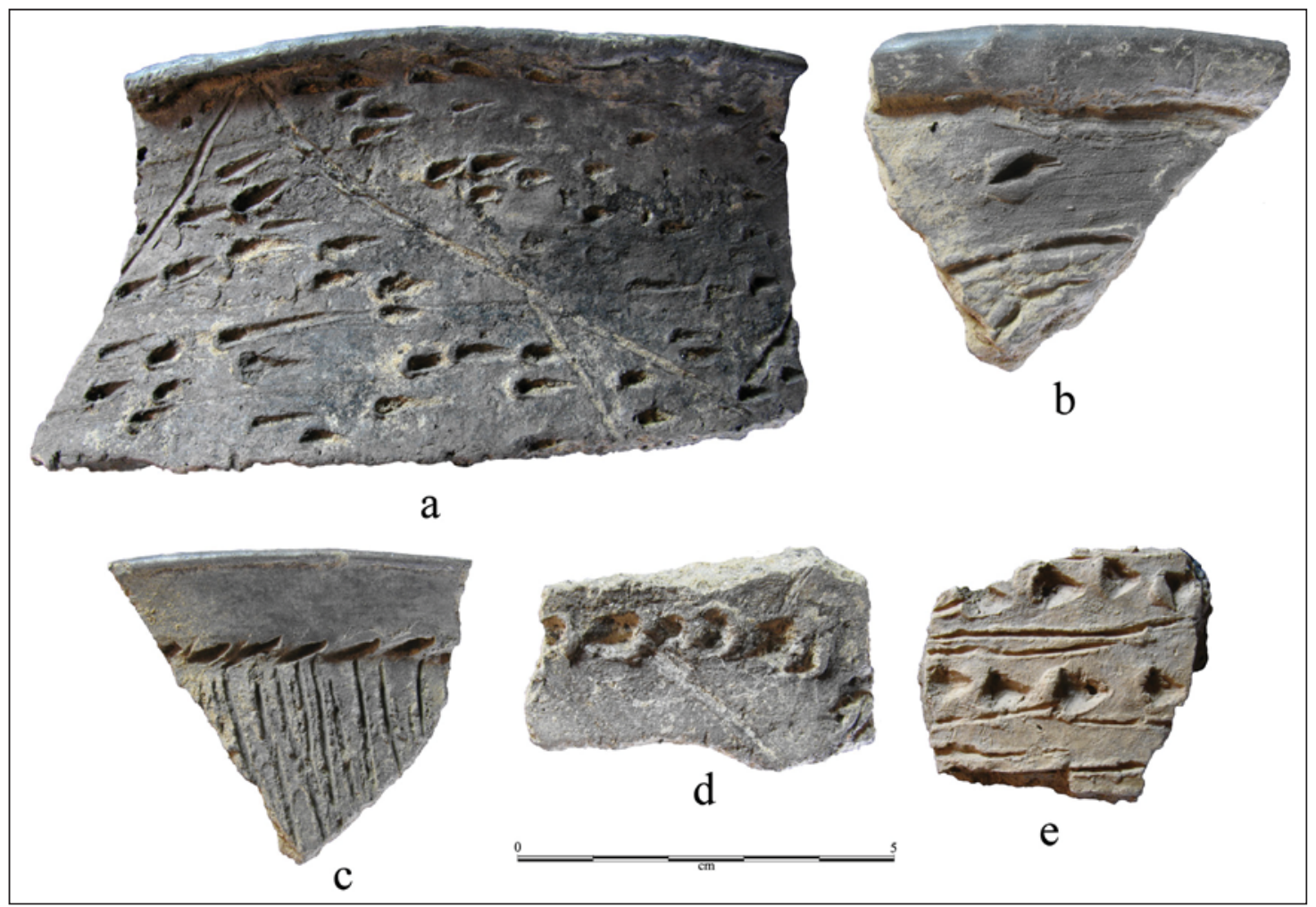

Figure 7. Incised-punctated rim and body sherds: a, Unit C, level 6; b, Unit A, level 6; c, Unit C, level 8; d, Unit A, level 7; e, Unit D, level 5.

The incised-punctated body sherds basically have the same set of decorative elements that characterize the incised-punctated rim sherds. Many of the body sherds have a tool punctated row adjacent to sets of incised lines running in various directions (Table 16), mostly diagonal or parallel lines (see Figure 7d). A few sherds have banded incised-punctated elements, where a row of tool punctates is placed between a set of horizontal or parallel incised lines (see Figure 7e). 


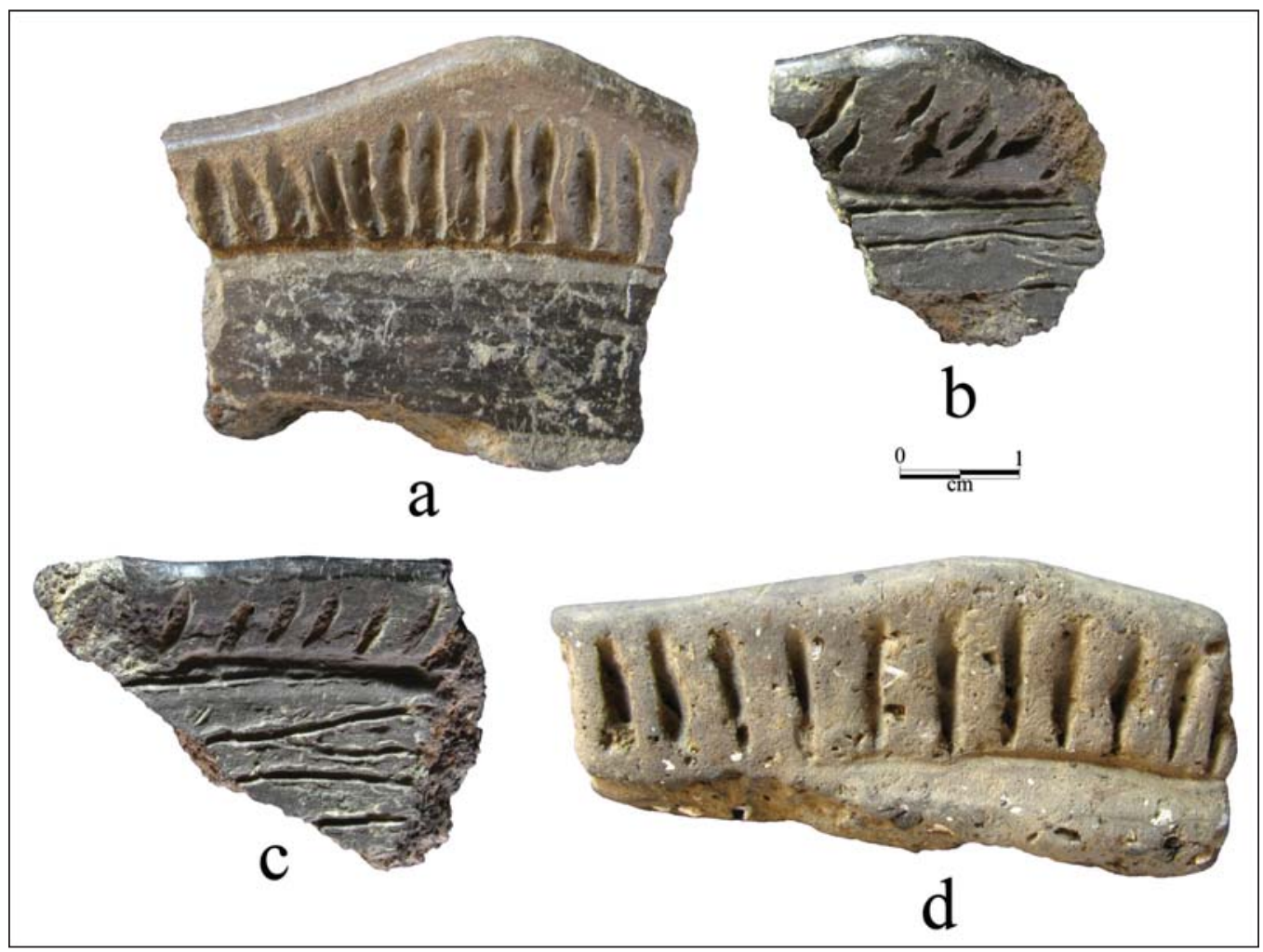

Figure 8. Incised-punctated rims on vessels with rim peaks: a, Unit A, level 9/10; b, Unit A, level 7; c, Unit A, level 8; d, Unit A, level 2.

Table 16. Decorative elements on incised-punctated body sherds.

\begin{tabular}{lrr}
\hline Decorative element & $\mathrm{N}$ & $\%$ \\
\hline banded incised lines-tool punctates between lines & 4 & 16.7 \\
& 1 & 4.2 \\
horizontal lines-tool punctated row & 7 & 29.2 \\
tool punctated row or rows-diagonal incised lines & 5 & 20.8 \\
tool punctated row-parallel incised lines & 1 & 4.2 \\
tool punctated row-straight incised line & 2 & 4.2 \\
tool punctated row-vertical incised lines & 1 & 12.5 \\
tool punctated row-horizontal incised line (lower rim)- & & 100.0 \\
vertical incised lines (body) & 3 & \\
incised triangle filled with tool punctates & 24 & \\
\hline Totals & & \\
\hline
\end{tabular}

One lower rim-body sherd has a horizontal incised line and a tool punctated row on the lower rim of a jar, and vertical incised lines on the vessel body (see Table 16 and Figure 9). Another incised-punctated body sherd is from a Maydelle Incised jar that has an incised triangle filled with tool punctations (see Suhm and Jelks 1962:103 and Plate 52e). 


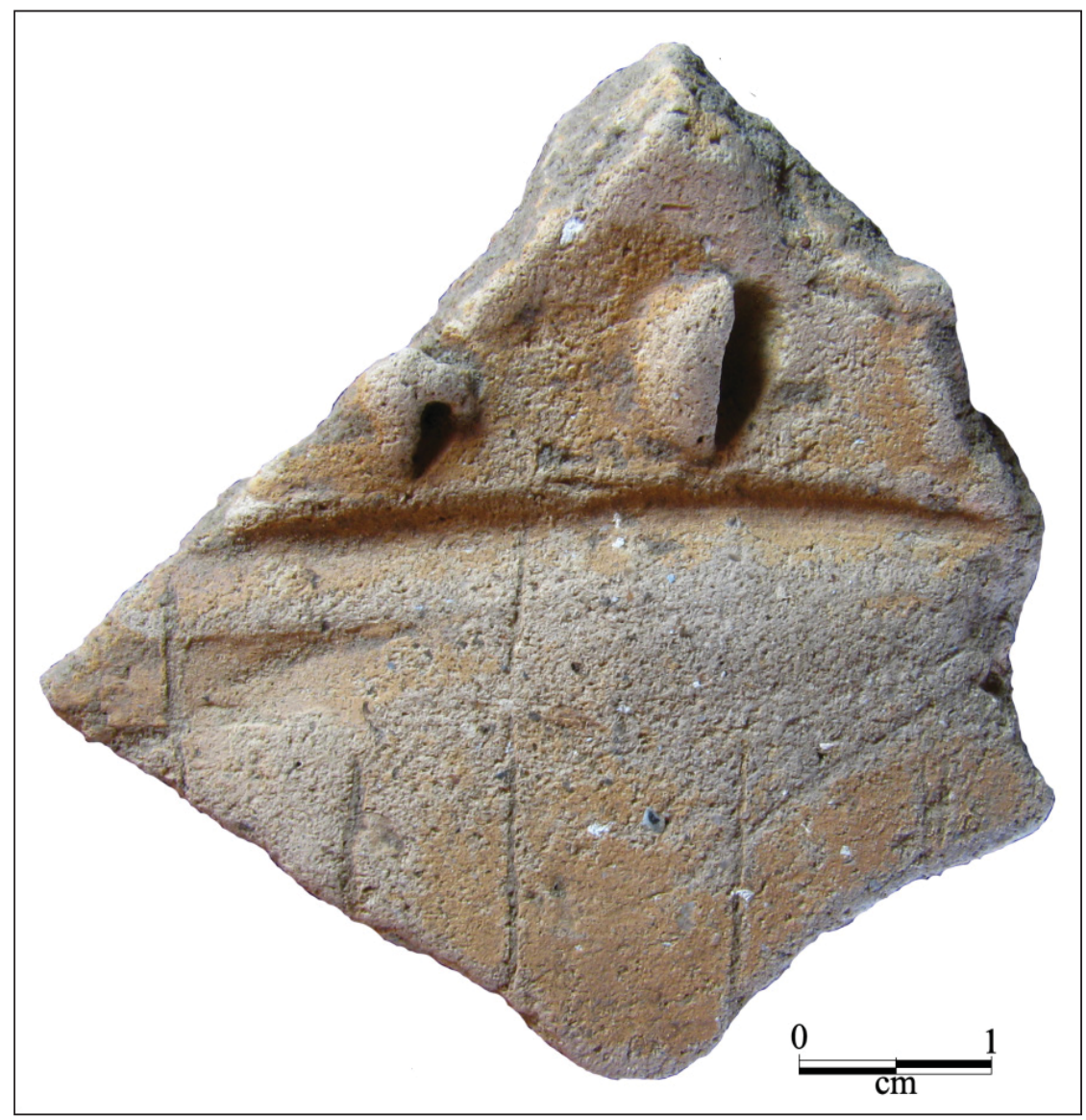

Figure 9. Incised-punctated lower rim and body sherd, Unit C, level 2.

\section{Neck Banded}

The few neck banded sherds $(n=4)$ in this ceramic assemblage from the Shelby Mound site are from La Rue Neck Banded jars (see Suhm and Jelks 1962:Plate 47) that have horizontal coil corrugations or neck bands around the vessel rim.

\section{Neck Banded-punctated}

One La Rue Neck Banded jar lower rim-body sherd has a horizontal row of tool punctations at the rimbody juncture, below the horizontal neck banding. The vessel body was apparently plain.

\section{Pinched}

The one body sherd with a pinched decoration (Unit D, level 9) in this Shelby Mound ceramic assemblage has parallel rows of pinching. This sherd may be from a Killough Pinched jar (see Suhm and Jelks 1962:Plate 46). 


\section{Punctated}

Sherds with punctated decorative elements comprise $4.7 \%$ of the utility wares from the mound deposits at the Shelby Mound site (see Table 4). Rim sherds are almost equally divided between sherds that have a row of tool punctations below the lip or have several rows of tool punctations that extend from below the lip to the rim-body juncture (Table 17 and Figure 10a-b). The latter may be from Mockingbird Punctated jars.

Table 17. Decorative elements on rims with punctations.

\begin{tabular}{lll}
\hline Decorative element & N & $\%$ \\
\hline Tool punctated row below the lip & 13 & 52.0 \\
Tool punctated rows on the rim & 12 & 48.0 \\
\hline Totals & 25 & 100.0 \\
\hline
\end{tabular}

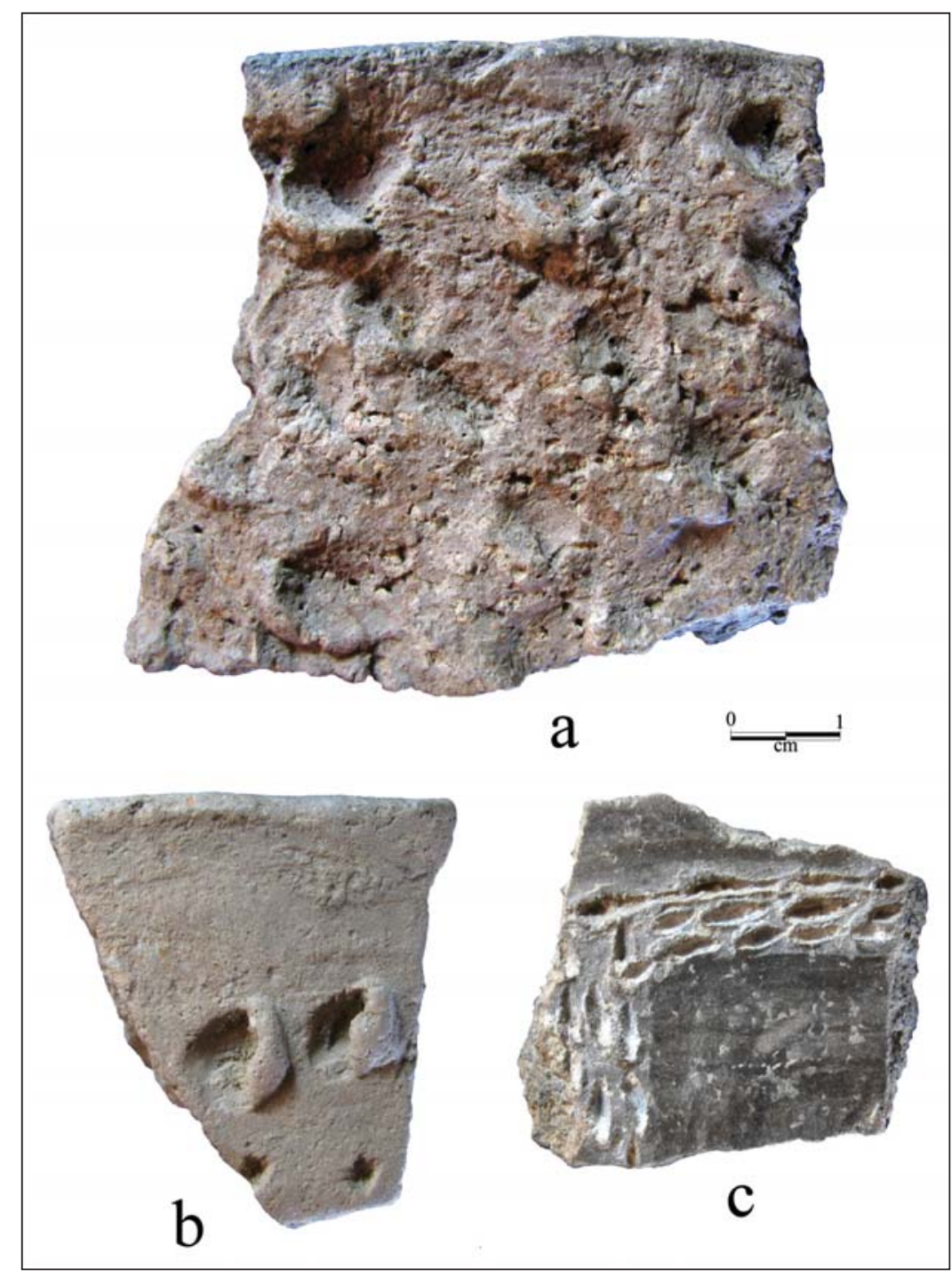

Figure 10. Punctated rim and body sherds: a, Unit A, level 2; b, Unit D, level 5; c, Unit A, level 9/10. 
Body sherds with punctated decorative elements $(n=47)$ include sherds with at least one row of tool punctates $(n=44,93.6 \%)$; sherds with only a single tool punctate $(n=2,4.3 \%)$; and a sherd (Unit A, levels 9/10) with a rectilinear tool punctated element (see Figure 10c). In most cases, it is likely that the punctated decorative elements on the body sherds simply represent the lower part of the rim, rather than that the vessel bodies also had rows of tool punctations.

\section{Fine Ware Sherds}

There are 478 fine ware sherds in the mound assemblage from Units A, C, and D: $0.8 \%$ trailed (Keno Trailed), $20.3 \%$ red-slipped, $1.3 \%$ engraved-punctated, $0.2 \%$ engraved-appliqued, and $77.4 \%$ with only engraved decorative elements (Table 18). These comprise almost $24 \%$ of the sherds from the decorated sherd assemblage recovered in the mound. Very similar proportions of the different fine wares were documented in the Area I village excavations in 2002 (Perttula and Nelson 2004:Table 6). More than $91.5 \%$ of the fine ware rims are from engraved vessels, and the remainder have only red-slipped decorations on both interior and exterior vessel surfaces. The few sherds with both engraved and appliqued or punctated decorative elements are body sherds (Table 18).

Table 18. Fine ware sherd assemblage from Units A, C-D.

\begin{tabular}{lccc}
\hline Decorative Method & Rim & Body & N \\
\hline Engraved & 76 & $294^{*}$ & 370 \\
Engraved-appliqued & - & 1 & 1 \\
Engraved-punctated & - & 6 & 6 \\
Red-slipped & 7 & $89^{* *}$ & 96 \\
Red-slipped/fabric-impressed & - & 4 & 1 \\
Trailed & - & 395 & 4 \\
\hline Totals & 83 & 478 \\
\hline
\end{tabular}

*includes one parallel-engraved, red-slipped sherd (cf. Avery Engraved) from Unit A, level 6

**includes one shell-tempered red-slipped sherd (cf. Avery Engraved or Clement Redware) from Unit C, level 5

Approximately $0.4 \%$ of the fine ware sherds are shell-tempered (see Table 18). These occur in the uppermost mound deposits (levels 5 and 6). The source of these sherds is likely vessels made by McCurtain phase Caddo potters living along the middle reaches of the Red River.

\section{Engraved rim and body sherds}

There are a wide range of decorative elements and motifs represented in the engraved rims from carinated bowls and compound bowls in the mound deposits at the Shelby Mound site (Table 19). The most basic element is simply a horizontal line under the vessel lip (see Figure 12e, below), typically the top line on a horizontal panel across the rim that is filled with an engraved design. In addition to the many rims with a single horizontal line in levels 1-5, there are circle and diamond elements from Ripley Engraved, var. McKinney (Perttula et al. 2012:Figure 9a), as well as other rims from Ripley Engraved, var. McKinney vessels with horizontal engraved lines and pendant triangles (Figures 11a-c). A number of the rims have scroll elements or scroll lines and scroll fill zones from Ripley Engraved vessels (Figures 12a-d and 13b-d). One sherd from a lower rim panel from a compound bowl is from a Turner Engraved vessel (Perttula et al. 2012:Figure 12a-d), although the variety cannot be identified. 
Table 19. Decorative elements on engraved rim sherds.

Decorative elements $\quad \mathrm{N}$

$\%$

Levels 1-5

Circle and diamond elements (Ripley Engraved,

var. McKinney)

Excised ovals under lip, and horizontal lines, one

with small excised pendant lines or tick marks

Hatched pendant triangles (Turner Engraved)

Horizontal line

Horizontal line under lip

Horizontal line and cross-hatched zone

Horizontal line and excised pendant triangles

(Ripley Engraved, var. McKinney)

Horizontal lines and narrow hatched zones 1

Horizontal line and slanting scroll line

Horizontal line and slanting scroll line with small

excised pendant triangles

Horizontal and vertical lines

Horizontal and vertical lines and embedded SZ element

Horizontal and vertical lines and excised pendant

Slanting scroll line and cross-hatched fill zone

Slanting scroll and hatched fill zone

Vertical line

Subtotal

Levels 6-7

Cross-hatched zone

Diagonal line

Diagonal line and diagonal hatched zone

Excised ovals under lip, and horizontal lines, one

with small excised pendant lines or tick marks

Horizontal line

Horizontal line and cross-hatched zone

Horizontal lines

Horizontal line and slanting scroll line

Scroll line and excised bracket

Vertical and diagonal lines with excised pendant triangles

25.0

Level 8

Hatched circle and vertical column elements 
Table 19. Decorative elements on engraved rim sherds, cont.

\begin{tabular}{lrr}
\hline Decorative elements & $\mathrm{N}$ & $\%$ \\
\hline Horizontal line and hatched vertical column & 1 & 5.6 \\
Horizontal lines and narrow hatched zone & 2 & 1.1 \\
Horizontal lines, narrow hatched zone, and SZ element & 1 & 5.6 \\
Horizontal and vertical lines and closely-spaced & 1 & 5.6 \\
$\quad$ curvilinear arc of lines & 1 & 5.6 \\
Sets of diagonal lines, closely-spaced & 18 & 100.0 \\
Subtotal & & \\
& & 8.3 \\
Levels 9-11 & 1 & 8.3 \\
Hatched triangle on interior rim-red-slipped & 3 & 8.7 \\
Horizontal line & 1 & 8.3 \\
Horizontal line with short incised lines on rim peak & 2 & 8.3 \\
Horizontal line under lip & 1 & 8.3 \\
Horizontal and vertical lines & 1 & 8.3 \\
Horizontal and vertical lines and large excised triangle & 1 & 100.0 \\
Horizontal and vertical lines and sideways hatched & & \\
$\quad$ triangle elements (Ripley Engraved, var. Reed) & 1 & \\
Slanting scroll line & 1 & \\
Vertical line & 12 & \\
Subtotal & 76 & \\
\hline Totals & & \\
\hline
\end{tabular}

*lower rim panel on compound bowl

Ripley Engraved elements are also prevalent in the levels 6-7 engraved rim sherds, with brackets, scroll lines, and excised pendant triangles (see Table 19). One distinctive decorated rim style found in levels 6-7 is also found in levels 1-5: it has excised ovals under the lip, and horizontal lines, one with small excised pendant lines or tick marks (see Figure 13a). A number of rims in Level 8 have hatched or cross-hatched zones and columns, and one has the Ripley Engraved SZ element (see Gadus 2013:Figure 5) on the rim (see Figure 11d); SZ elements are also found on Ripley Engraved carinated bowls in the upper mound levels (see Figure 12a) and Ripley Engraved bottles. The most distinctive rims in levels 9-11 have large excised triangles and sideways hatched triangle elements (see Table 19), the latter from a Ripley Engraved, var. Reed vessel (see Perttula et al. 2012:Figure 9i).

The more distinctive engraved decorative elements on fine ware body sherds in the mound deposits are listed by analytical unit in Table 20. Almost all of these sherds are from the lower part of the rim on carinated bowls, but the lip is missing, so they are categorized as body sherds in the assemblage. Hatched, cross-hatched, and excised zones and brackets from Ripley Engraved vessels are common in levels 1-5 in the mound deposits, as are circle elements, excised pendant triangles, and triangles filled with hatched or cross-hatched engraved lines (Figure 14b-c, f). Distinctive hooked arm and negative oval elements are from Taylor Engraved and Hodges Engraved vessels (Table 20 and Figure 15a-c).

Circle elements and hatched, cross-hatched, and excised zones or brackets are also prevalent in levels 6-7, along with elements from scroll motifs on Ripley Engraved vessels (see Table 20). In addition to the narrow hatched, cross-hatched, or excised zones in Level 8 engraved body sherds, there are body sherds with large excised, hatched, cross-hatched, and open triangle elements (see Table 20); these may be from 


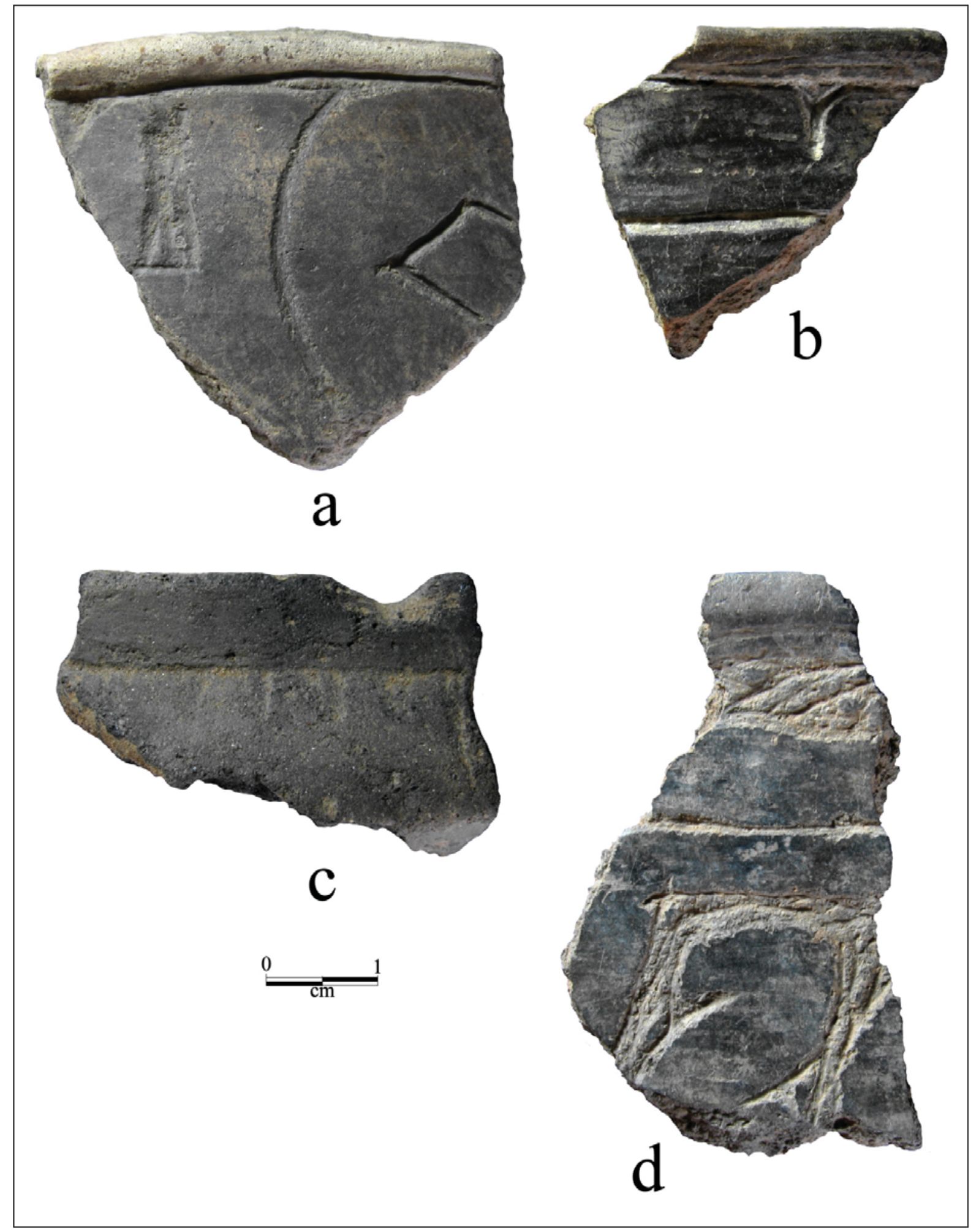

Figure 11. Ripley Engraved rim sherds: a, Unit D, level 2; b, Unit A, level 5; c, Unit D, level 3; d, Unit D, level 8. 


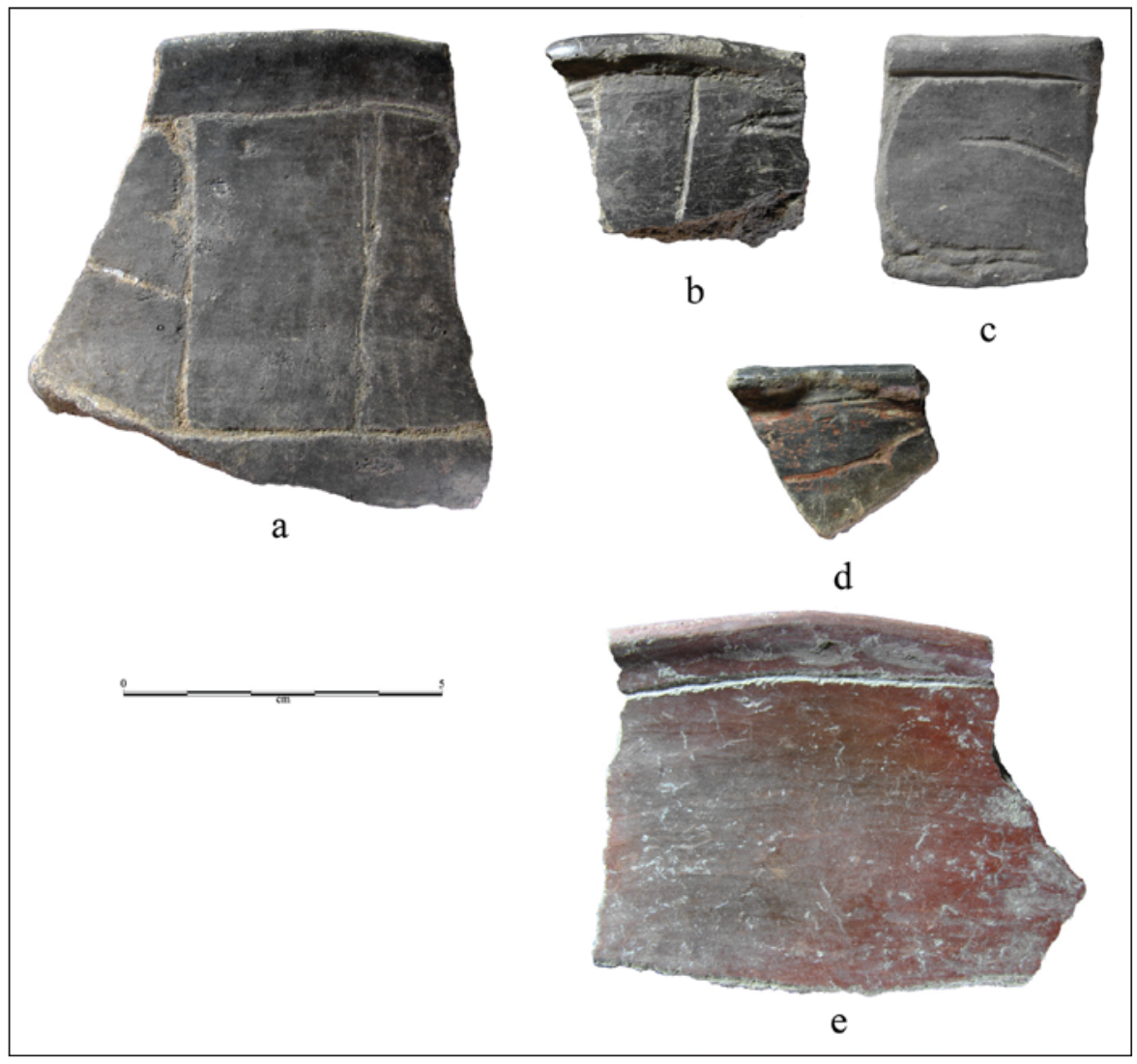

Figure 12. Additional Ripley Engraved rim sherds: a, Unit C, level 5; b, Unit A, levels 9/10; c, Unit D, level 6; d, Unit C, level 4; e, Unit D, level 8.

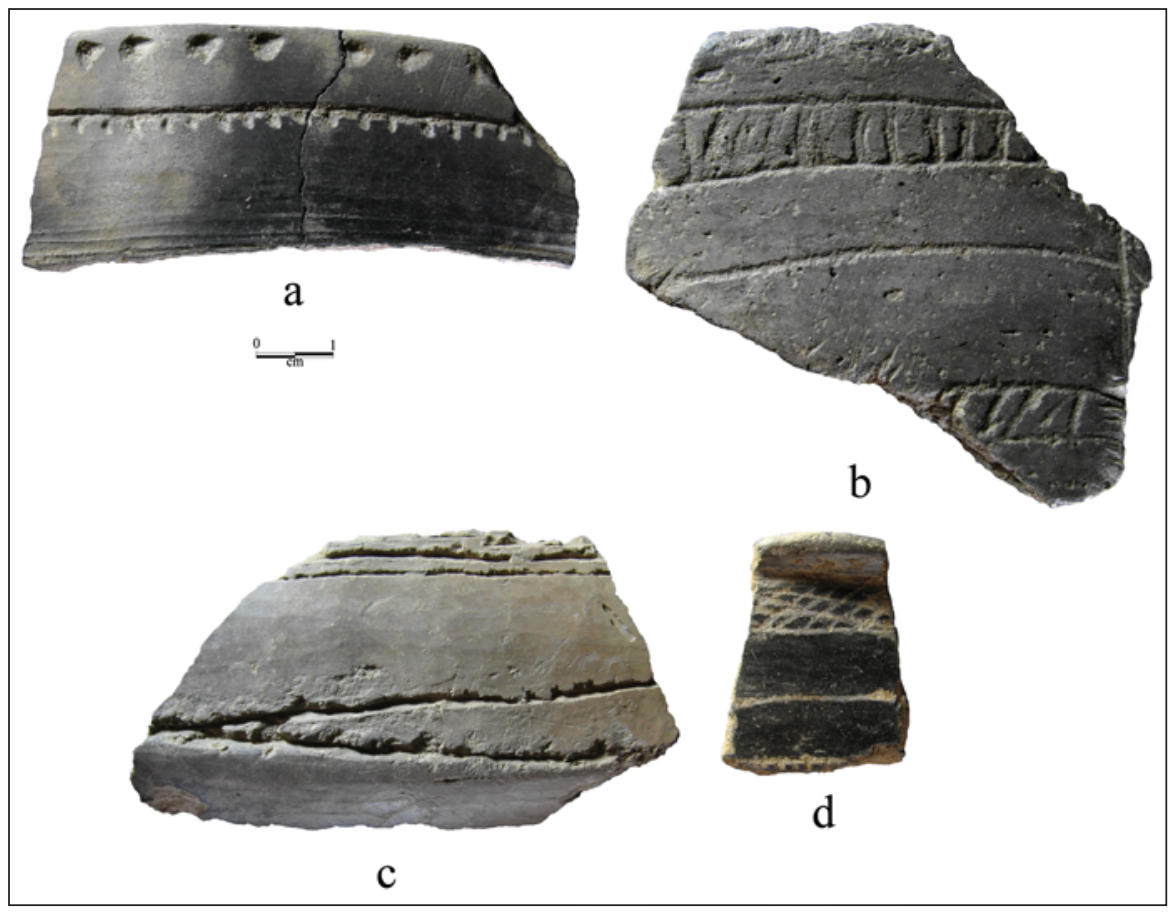

Figure 13. Engraved rims from the Shelby Mound site: a, Unit D, level 2; b, Unit D, level 5; c, Unit D, level 9; d, Unit D, level 7. 
Table 20. Distinctive decorative elements on engraved carinated bowl and compound bowl body sherds.

Decorative elements

Levels $1-5$

circle element

2

circle element and cross-hatched zone

2

circle element with inner swastika in a circle

cross-hatched zone

1

cross-hatched pendant triangle

7

curvilinear excised zone

1

excised bracket

3

excised zone

1

hatched bracket

1

hatched circle

2

hatched zone

hatched scroll fill zone

hooked arm element (Taylor Engraved)

horizontal line and cross-hatched zone

horizontal-diagonal hatched zones

narrow excised zone

narrow hatched zone and curvilinear line

negative ovals (Hodges Engraved)

parallel lines and hatched/cross-hatched triangle

parallel lines with excised pendant triangles

parallel lines and cross-hatched zone

slanted scroll line

straight line with excised pendant triangles

straight line with hatched triangle

Subtotal

Levels 6-7

circle element

circle element and narrow curvilinear hatched zone

continuous scroll element

cross-hatched zone

excised bracket

hatched scroll fill zone

narrow hatched zones

pendant triangle element

slanted scroll line

slanted scroll line and cross-hatched scroll fill zone

straight line and hatched columns

Subtotal

Level 8

circle and circular excised zone

circular element and excised bracket

cross-hatched zone

cross-hatched triangle element 
Table 20. Distinctive decorative elements on engraved carinated bowl and compound bowl body sherds, cont.

Decorative elements $\quad \mathrm{N}$

excised zones 3

excised pendant triangle $\quad 1$

excised triangle 3

hatched bracket 4

narrow excised zone 4

narrow hatched zone 1

parallel lines with hatched and open triangles 1

parallel lines and large cross-hatched triangle el.

straight line with excised triangle $\quad 1$

vertical hatched zone 1

Subtotal 24

Levels 9-11

circle element 2

cross-hatched bracket $\quad 1$

curvilinear element with excised pendant triangle and $\quad 1$

excised bracket

hatched scroll fill zone $\quad 2$

horizontal and diagonal lines and closely-spaced $\quad 1$

diagonal hatched zone (Ripley Engraved, var. Carpenter)

narrow hatched zone $\quad 1$

parallel lines and excised triangles $\quad 1$

parallel lines and narrow excised zone $\quad 1$

parallel lines and short excised lines $\quad 1$

slanted scroll line $\quad 2$

straight line with excised pendant triangles $\quad 1$

$\begin{array}{ll}\text { Subtotal } & 14\end{array}$

$\begin{array}{lr}\text { Totals } & 89\end{array}$

Turner Engraved, var. Turner and var. Horton compound bowls. In the lowermost levels of the mound deposits at the Shelby Mound site (levels 9-11), elements of engraved circle elements, cross-hatched zones, and scrolls from Ripley Engraved vessels are common (see Figure 14a, d-e, h), including one sherd from a Ripley Engraved, var. Carpenter vessel (see Perttula et al. 2012:Figure 9f) with part of a continuous scroll motif. A few other sherds have excised pendant triangles or ticking on parallel or straight lines (Figure 16b, f), although one distinctive Ripley Engraved body sherd has a curvilinear element with excised pendant triangles and excised brackets (see Table 20).

Another distinctive sherd from the lower mound deposits (Level 10) is red-slipped on both interior and exterior surfaces, has a scalloped rim, and an engraved hatched triangle element on the inner rim surface (see Figure 16c). This rim may be from a Bowie Engraved vessel (see Suhm and Jelks 1962:17 and Plate 9).

Engraved sherds from bottles in the mound deposits at the Shelby Mound site tend to have curvilinear lines, cross-hatched zones, and circular elements (Table 21 and see also Figures 15g and 16d-e). Most of these are from Ripley Engraved bottles (see Suhm and Jelks 1962:Plate 65b-d, f, h-j; Perttula et al. 


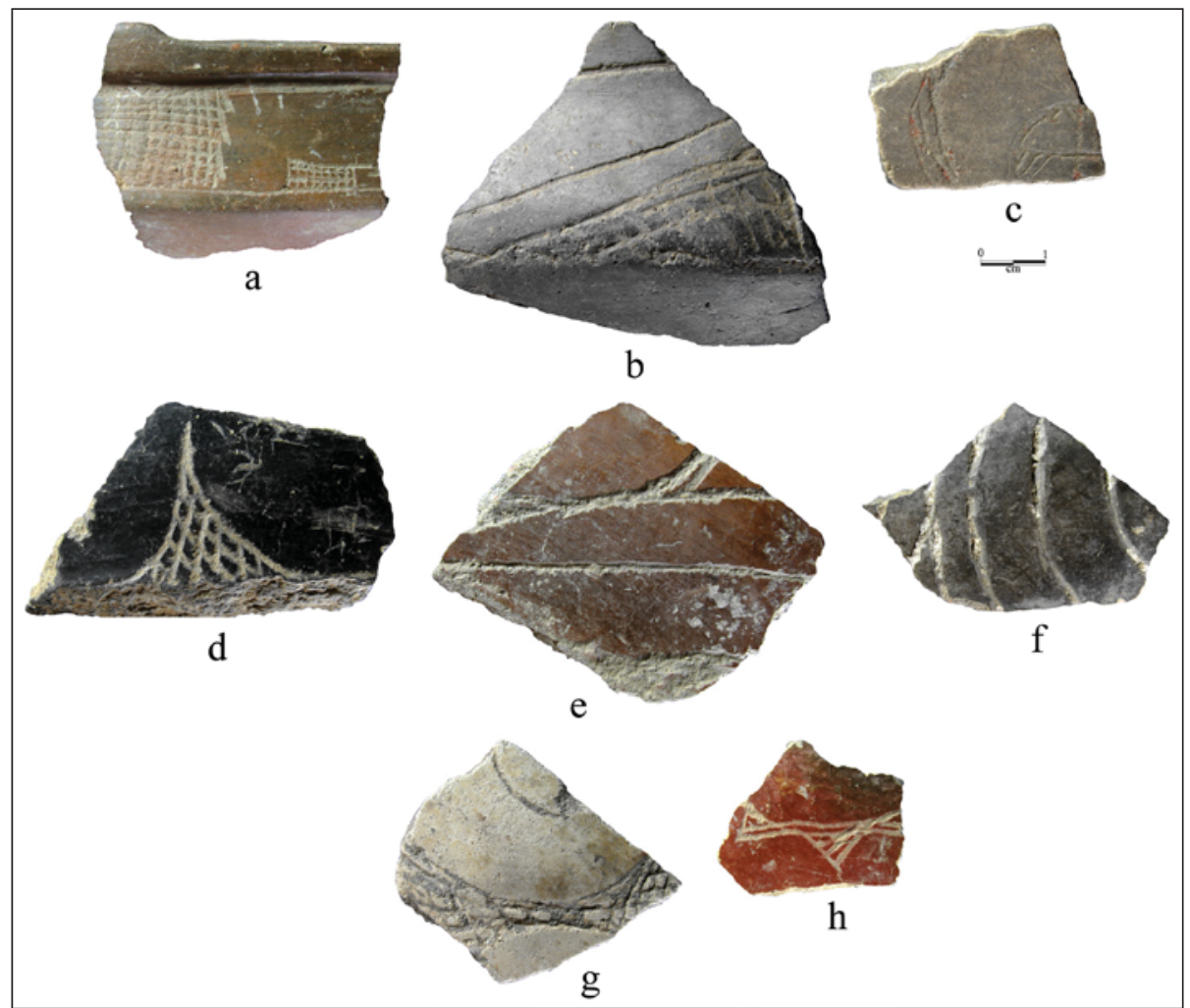

Figure 14. Engraved elements on body sherds: a, Unit D, level 8; b, Unit D, level 5; c, Unit D, level 1; d, Unit D, level 8; e, Unit D, level 10; f, Unit A, level 4; g, bottle sherd, Unit C, level 5; h, Unit A, level 8.

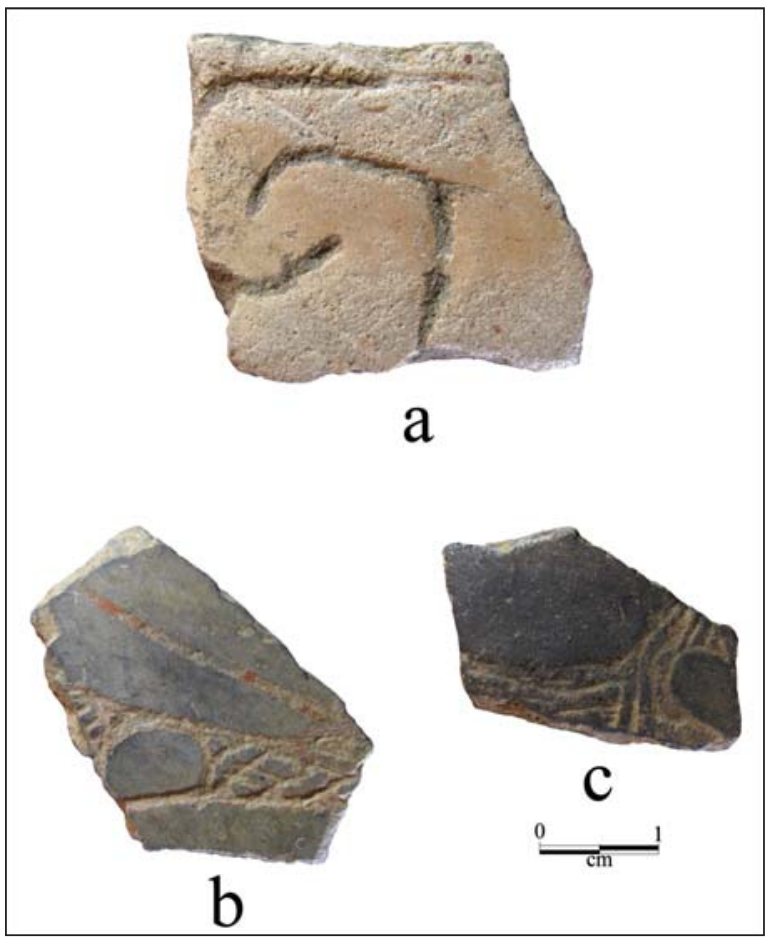

Figure 15. Taylor Engraved and Hodges Engraved sherds: a, Taylor Engraved, Unit D, level 2; b, possible Hodges Engraved, Unit A, level 9; c, Hodges Engraved, Unit D, level 2. 


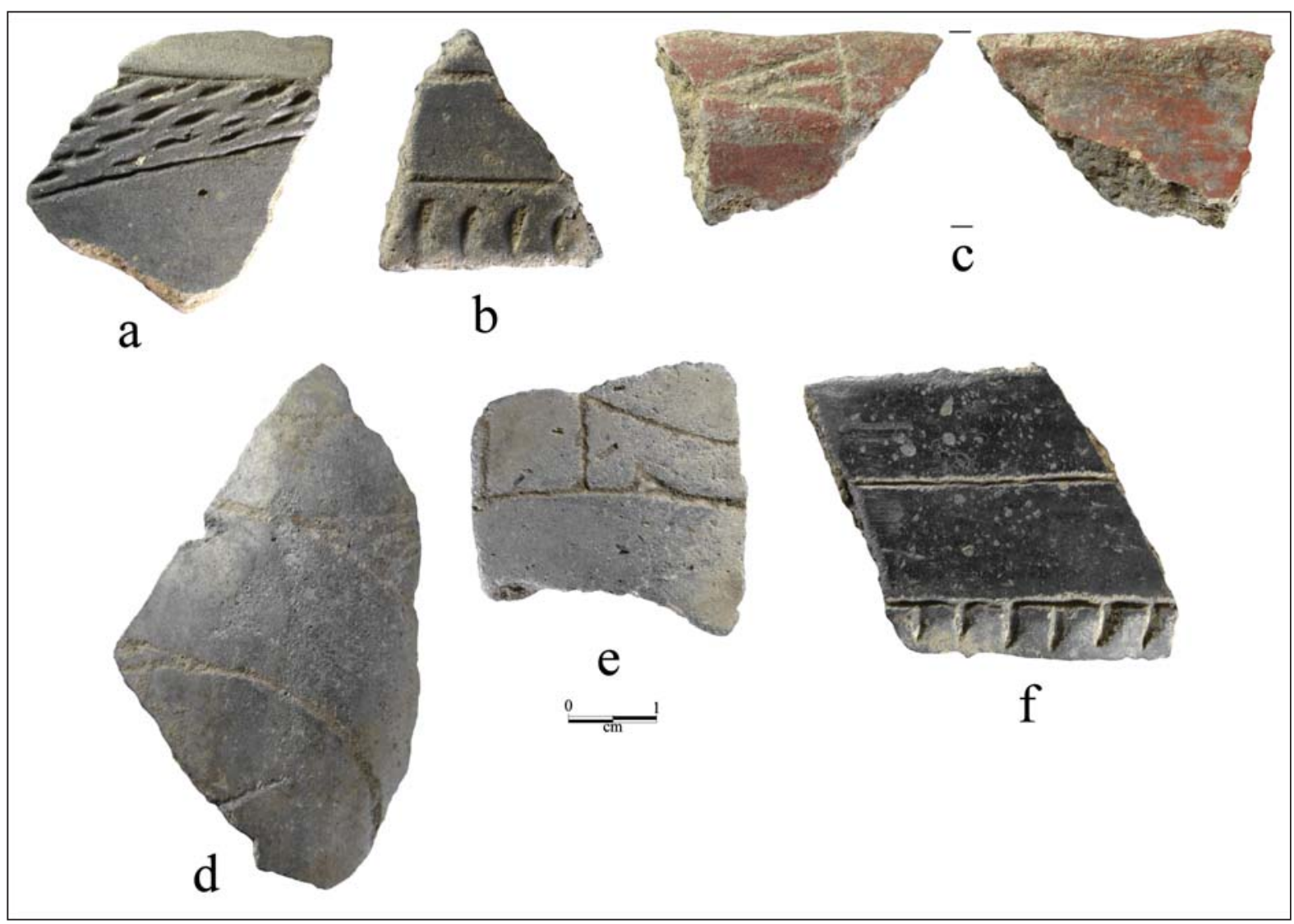

Figure 16. Distinctive engraved carinated bowl and bottle sherds: a, Unit D, level 1; b, Unit C, level 4; c, Unit D, level 10; d, Unit D, level 6; e, Unit D, level 6; f, Unit D, level 10.

2012:Figure 10; Gadus 2013:Figure 1), including several sherds in levels 1-5 that have excised, hatched, or open pendant triangles. One of the bottle sherds in Level 6 has a SZ element (see Figure 16e). None of the engraved bottle sherds in the engraved fine wares in the mound deposits have the distinctive encircling scrolls or swirl motifs and circular elements of the Wilder Engraved type (Suhm and Jelks 1962:Plate 78d-i, 1); Perttula et al. 2012:Figure 11a-d; Gadus 2013:Figure 7a-g). Nevertheless, Wilder Engraved bottles are one of the more common fine wares documented in the ceramic vessel funerary assemblage at the Shelby Mound site (Perttula et al. 2012).

Red $(n=9)$ and white $(n=11)$ clay pigments were occasionally rubbed in the engraved designs on the sherds from carinated bowls, compound bowls, and bottles. Approximately 5.3\% of the engraved sherds have applied pigments; in the village area $6 \%$ of the engraved sherds had either a red or white pigment rubbed in the decoration (Perttula and Nelson 2004:40-41). Engraved vessels in the mound deposits at the Shelby Mound site also had a red slip applied to one (bottles) or both surfaces (bowls, carinated bowls, and compound bowls). There are 23 engraved sherds in the assemblage with a red slip, approximately $6.2 \%$ of the fine wares with engraved decorations; $6 \%$ of the engraved sherds in the village area had a red slip on interior and exterior surfaces (Perttula and Nelson 2004:41).

Eight engraved sherds from a single bottle were recovered in Unit D, level 1 . The bottle is heavily eroded, but the decorative element appears to be sets of curvilinear lines and excised zones. There is also one notable engraved rim sherd (Unit D, level 10) that has a red slip on both vessel surfaces and an engraved element on its interior beveled rim. The decorative element is a sideways hatched triangle. 
Table 21. Decorative elements on engraved carinated bottle body sherds.

\begin{tabular}{lcc}
\hline Decorative elements & $\mathrm{N}$ & $\%$ \\
\hline Levels 1-5 & 1 & 7.1 \\
cross-hatched bracket and curvilinear line & 6 & 42.9 \\
curvilinear lines & 3 & 21.4 \\
curvilinear line and excised pendant triangles & 1 & 7.1 \\
curvilinear lines and hatched pendant triangle & 1 & 7.1 \\
opposed lines & 1 & 7.1 \\
opposed circular elements and excised bracket & 1 & 7.1 \\
opposed curvilinear lines and open pendant triangle & 14 & 66.7 \\
Subtotal & & 33.3 \\
& & 33.3 \\
Levels 6-7 & & 33.3 \\
opposed lines & 1 & 14.3 \\
opposed circular elements & 1 & \\
SZ element & 1 & 4.8 \\
Subtotal & 3 & 33.3 \\
Level 8 & & 33.3 \\
straight line/red-slipped & & 14.3 \\
& 1 & \\
Levels 9-11 & & \\
curvilinear lines, cross-hatched zones, and negative oval & & \\
curvilinear line and hatched triangle & & \\
Subposed curvilinear lines & 1 & 1 \\
\hline Totals & 1 & \\
\hline
\end{tabular}

There are also four sherds (Unit A, level 8, $\mathrm{n}=1$; Unit A, level 9, $\mathrm{n}=1$; Unit $\mathrm{D}$, level 8, $\mathrm{n}=2$ ) from an engraved carinated bowl that has been refired, probably because they were exposed to fire when a structure was burned down in or near the mound; the surface of the sherds are bubbly and the sherds are very light in weight because of the materials burned out of the vessel core during the refiring of the vessel. The sherds have horizontal engraved lines that alternate with two narrow horizontal zones filled with vertical hatched lines that alternate with areas on the rim that have single vertical lines and closely-spaced arcs of lines.

\section{Engraved-appliqued}

The one engraved-appliqued sherd in the fine ware sherds is from Unit C, level 8. It has a straight appliqued ridge and an adjacent excised zone. 


\section{Engraved-punctated}

There are six engraved-punctated body sherds in the Shelby Mound ceramic assemblage from mound deposits, all from the upper mound fill deposits (1.3\% of the fine wares, see Table 18). One of the sherds has parallel engraved lines and a row of excised tool punctates (Unit C, level 4); two sherds in Unit D (level 1) have circles or scroll fill zones with punctates (see Figure 16a); and three others (Unit C, level 2) are from a Bailey Engraved bottle with curvilinear engraved zones filled with excised punctates. About $2.8 \%$ of the fine wares in the Area I village at the site have engraved-punctated elements, including one Bailey Engraved bottle sherd (Perttula and Nelson 2004:41).

\section{Red-slipped}

The red-slipped rim and body sherds are from bowls, carinated bowls, and bottles decorated simply with a hematite-rich clay slip; they comprise $20 \%$ of the fine wares (see Table 18) and $8.4 \%$ of the fine ware rims in the mound deposits. Approximately $24.3 \%$ of the fine wares in the Area I village at the Shelby Mound site are red-slipped, including 6.3\% of the fine ware rims (Perttula and Nelson 2004:Table 6).

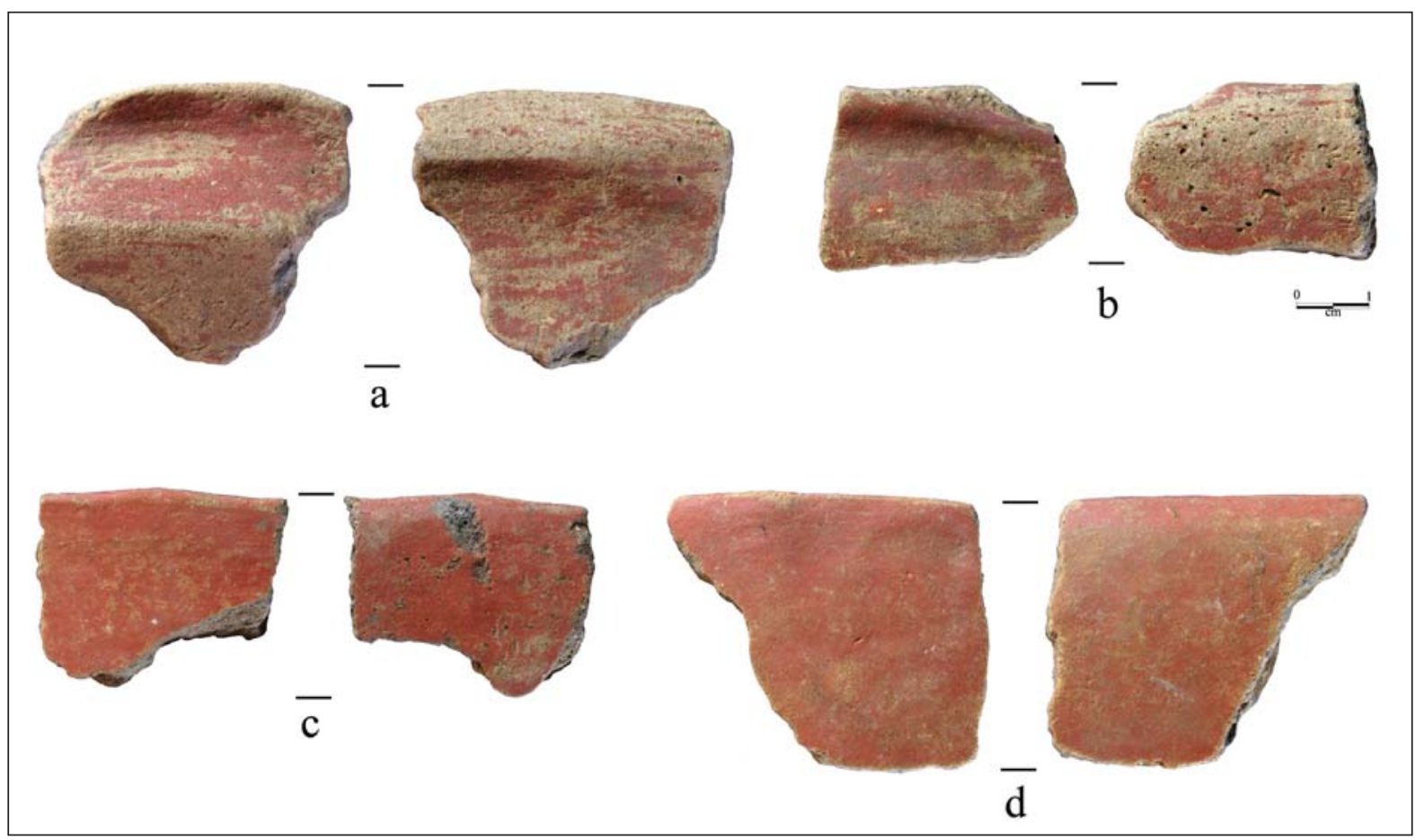

Figure 17. Red-slipped rim sherds: a, Unit D, level 1; b, Unit C, level 2; c, Unit D, level 1; d, Unit D, level 5.

All seven rims have a red slip on both interior and exterior surfaces (Figure 17a-d). On the body sherds, $73(82 \%)$ have a red slip on both surfaces (including one from a shell-tempered vessel, possibly an undecorated portion of an Avery Engraved vessel or a Clement Redware vessel, see Flynn [1976]), and 16 (18\%), most likely all from bottles, have a red slip on their exterior surface. 


\section{Red-slipped/fabric-impressed}

One body sherd (Unit D, level 5), probably from a bowl, had a simple fabric-impressed decorative element on its exterior surface while its interior surface had a red slip. The use of fabric impressions for vessel decoration has not been previously documented in Big Cypress Creek basin Titus phase ceramic assemblages.

\section{Trailed}

There are several Keno Trailed bowl sherds with multiple curvilinear or diagonal opposed trailed line decorations in the mound deposits (Figure 18a-c). They generally occur in the uppermost mound/midden fill (see Table 3).

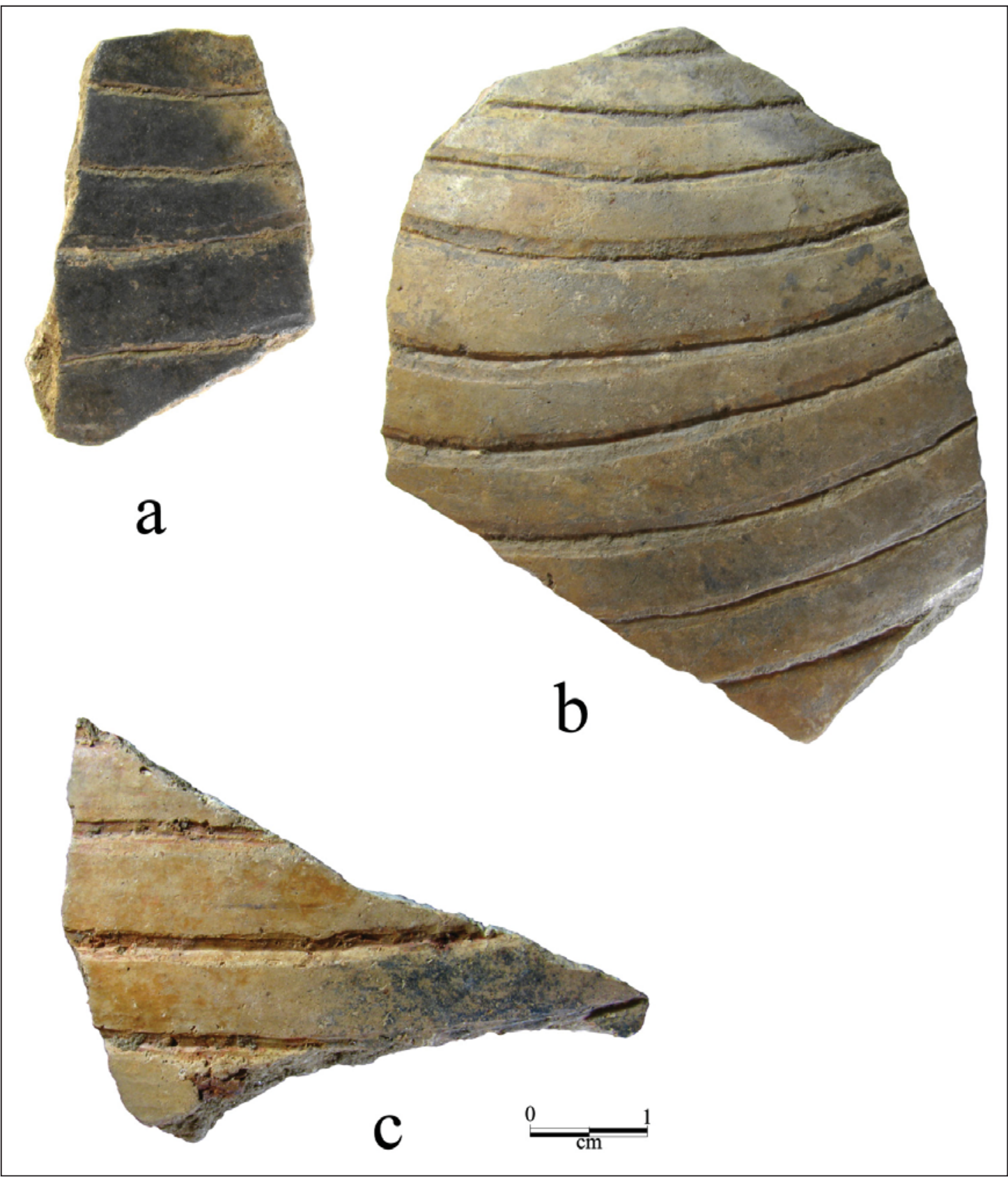

Figure 18. Keno Trailed bowl sherds: a, Unit A, level 1; b, Unit D, level 3; c, Unit A, level 5. 


\section{Distinctive Sherd Attributes}

Although not common, several of the rim sherds have distinctive rim peaks; there would have been four such peaks around the rim of utility ware jars, plain jars $(n=1)$, as well as fine ware carinated bowls. This includes a fine ware rim with cross-hatched engraved zones (Unit D, level 8); a fine ware rim with short vertical incised lines under the rim peak and horizontal engraved lines on the rim itself (Unit A, levels 9/10); a jar with horizontal lines and tool punctated rows (Unit A, level 7); a jar with tool punctates below the lip (Unit A, level 6); and a third jar rim with vertical incised lines (Unit A, level 2). Approximately 2.3\% of the rims in the ceramic assemblage have rim peaks, including $1.4 \%$ of the plain rims, $2.8 \%$ of the utility ware rims, and $2.4 \%$ of the fine ware rims.

\section{Pipe Sherds}

A single clay elbow pipe bowl rim sherd, a common Late Caddo period pipe form in East Texas, was recovered in Unit $\mathrm{D}$, level 3 , in the mound deposits. The bowl was not decorated.

\section{Clay Coil Fragments}

Evidence of ceramic vessel manufacture on site by Caddo potters includes clay coil fragments. Two such fragments are in the collection: one from level 1 in Unit D and one from level 3 in Unit C.

\section{SUMMARY AND CONCLUSIONS}

The mound deposits at the Shelby Mound site contain an abundant assemblage of plain and decorated sherds from plain ware, utility ware, and fine ware vessels. More than 2590 decorated rim and body sherds have been recovered in a single 10 x $10 \mathrm{ft}$. unit (divided into four 5 x $5 \mathrm{ft}$. units labeled A-D) excavated in the mound, and this article primarily discusses the decorated sherds from units A, C, and D, as the decorated sherds from Unit B were previously discussed by Perttula and Nelson (2004:18-20).

The decorated sherds are dominated by utility wares (sherds from jars with wet paste decorations) - approximately $76 \%$ of the decorated sherd assemblage - particularly sherds from jars with brushed, incised, brushed-incised, and punctated decorative elements on vessel rim and/or body, but there are a wide variety of other wet paste decorative combinations (see Tables 3 and 4). The fine ware sherds, namely sherds with engraved, engraved-appliqued, engraved-punctated, red-slipped, and trailed decorative elements and motifs, comprise about $24 \%$ of the decorated sherds in the mound deposits (see Table 18). Particularly distinctive in the assemblage is the considerable amount of sherds from red-slipped bowls and bottles, as this is apparently a feature of western Titus phase ceramic assemblages in the Big Cypress Creek basin.

The identified types and varieties in the mound deposits include a consistent range of utility wares, Bullard Brushed (in all mound levels), Cass Appliqued (in the upper mound deposits only), Harleton Appliqued, La Rue Neck Banded (upper mound levels), Maydelle Incised, Mockingbird Punctated, and Pease Brushed-Incised (in all mound levels). The identified fine wares include sherds from Bailey Engraved bottles (in the upper mound levels only), Hodges Engraved and Keno Trailed sherds (in the upper mound levels only), Ripley Engraved, var. Carpenter (upper mound levels), Ripley Engraved, var. Gandy, Ripley Engraved, var. McKinney (upper mound levels), Ripley Engraved, var. Ripley bottles, Ripley Engraved, var. unspecified (in all mound levels, Taylor Engraved (in upper mound levels only), Turner Engraved, var. unspecified in the upper mound levels only, and Avery Engraved (levels 6-7). Sherds from a Ripley Engraved, var. Reed vessel were found only in the lowest mound levels (levels 9-11). The upper mound levels also are characterized by engraved-punctated sherds, a fabric-impressed and red slipped sherd, and sherds with the 
engraved SZ elements; sherds with the SZ element are also present in levels 6-7 and Level 8. Red-slipped fine ware vessel sherds are present throughout the mound deposits. The principal fine ware in all levels of the mound at the Shelby Mound site is Ripley Engraved, and Ripley Engraved, var. McKinney is the most common variety, albeit confined to the upper mound levels.

The upper mound levels - levels 1-5-are characterized by several ceramic types indicative of the late Titus phase, dating from ca. A.D. 1550-1680. This includes sherds from Cass Appliqued, Hodges Engraved, Keno Trailed, Taylor Engraved, and Ripley Engraved, var. McKinney vessels, especially the latter. This suggests that the uppermost mound fill came from sediments and midden deposits gathered from the adjoining village areas, which were also occupied at this time. The lower mound deposits, levels 6-7, Level 8 , and 9-11, appear to be associated with special purpose house construction/destruction (by burning) and several levels of mound fill zones that took place in the $15^{\text {th }}$ to early $16^{\text {th }}$ century, during the early Titus phase, from ca. A.D. 1430-1550. Sherds from Ripley Engraved, var. Carpenter, var. Gandy, and var. Reed, as well as Ripley Engraved, var. unspecified vessels have been identified in the lowest levels of the mound at the Shelby Mound site.

\section{ACKNOWLEDGMENTS}

I very much appreciate the opportunity provided by Robert L. Turner and Bo Nelson to analyze the ceramic sherds from the Shelby Mound in the Turner collection. Lance Trask prepared the map and photographic images.

\section{REFERENCES CITED}

Brown, J. A.

1996 The Spiro Ceremonial Center: The Archaeology of Arkansas Valley Caddoan Culture in Eastern Oklahoma. 2 Vols. Memoirs No. 29. Museum of Anthropology, The University of Michigan, Ann Arbor.

Fields, R. C. and E. F. Gadus (editors)

2012 Archeology of the Nadaco Caddo: The View from the Pine Tree Mound Site (41HS15), Harrison County, Texas. 2 Vols. Reports of Investigations No. 164. Prewitt and Associates, Inc., Austin.

Flynn, P.

1976 A Study of Red-Filmed Pottery from the Clement Site (Mc-8), McCurtain County, Oklahoma. Bulletin of the Oklahoma Anthropological Society 25:127-134.

Gadus, E. F.

2013 Twisted Serpents and Fierce Birds: Structural Variation in Caddo Engraved Ceramic Bottle Motifs. Bulletin of the Texas Archeological Society 84:213-245.

Gonzalez, B., R. L. Cast, T. K. Perttula, and B. Nelson

2005 A Rediscovering of Caddo Heritage: The W. T. Scott Collection at the American Museum of Natural History and Other Caddo Collections from Arkansas and Louisiana. Historic Preservation Program, Caddo Nation of Oklahoma, Binger.

Mitchell, S. A.

2000 Data Salvage Project: Greasy Creek Study. Report on file, Texas Archeological Research Laboratory, The University of Texas at Austin.

Perttula, T. K.

1998 Late Caddoan Societies in the Northeast Texas Pineywoods. In The Native History of the Caddo: Their Place in Southeastern Archeology and Ethnohistory, edited by T. K. Perttula and J. E. Bruseth, pp. 69-90. Studies in Archeology 30. Texas Archeological Research Laboratory, The University of Texas at Austin. 
2000 Functional and Stylistic Analyses of Ceramic Vessels from Mortuary Features at a $15^{\text {th }}$ and $16^{\text {th }}$ Century Caddo Site in Northeast Texas. Midcontinental Journal of Archaeology 25(1):101-151.

2004 The Prehistoric and Caddoan Archeology of the Northeastern Texas Pineywoods. In The Prehistory of Texas, edited by T. K. Perttula, pp. 370-407. Texas A\&M University Press, College Station.

2009 A Radiocarbon Date from a Cedar Pole in a Special Caddo Burial Feature at the Shelby Mound site (41CP71). Texas Archeology (Newsletter of the Texas Archeological Society) 53(1):20-21.

2012 The Character of $15^{\text {th }}$ to $17^{\text {th }}$ Century Caddo Communities in the Big Cypress Creek Basin of Northeastern Texas. In The Archaeology of the Caddo, edited by T. K. Perttula and C. P. Walker, pp. 363-410. University of Nebraska Press, Lincoln.

2013 Archeological Investigations at the Kitchen Branch (41CP220), B. J. Horton (41CP20), and Keering (41CP21) Sites, Big Cypress Creek Basin, Camp County, Texas. AmaTerra Environmental, Inc., Austin.

2014 The Classification of Late Caddo Period Utility Ware Jars from Sites in the Big Cypress Creek Basin of East Texas. Caddo Archeology Journal 24:53-74.

Perttula, T. K. (editor)

2005 Archeological Investigations at the Pilgrim's Pride Site (41CP304), a Titus Phase Community in the Big Cypress Creek Basin, Camp County, Texas. 2 Vols. Report of Investigations No. 30. Archeological \& Environmental Consultants, LLC, Austin.

Perttula, T. K., P. S. Marceaux, and B. Nelson

2012 Study of the Margaret Hinton Collection of Pottery Vessels from Northeast Texas Caddo Cemeteries. Report of Investigations No. 126. Archeological \& Environmental Consultants, LLC, Austin.

Perttula, T. K. and B. Nelson

1998 Titus Phase Mortuary Practices in the Northeast Texas Pineywoods and Post Oak Savanna. In Analysis of the Titus Phase Mortuary Assemblage at the Mockingbird or "Kahbakayammaahin" Site (41TT550), by T. K. Perttula, M. Tate, H. Neff, J. W. Cogswell, M. D. Glascock, E. Skokan, S. Mulholland, R. Rogers, and B. Nelson, pp. 328-401. Document No. 970849. Espey, Huston \& Associates, Inc., Austin.

2004 Archeological Investigations at the Shelby Site (41CP71) on Greasy Creek, Camp County, Texas. Special Publication No. 5. Friends of Northeast Texas Archaeology, Pittsburg and Austin.

Perttula, T. K. and R. Z. Selden, jr.

2013 New Radiocarbon Dates from East Texas Caddo Sites. Journal of Northeast Texas Archaeology 40:1926.

Perttula, T. K. and D. L. Sherman

2009 Data Recovery Investigations at the Ear Spool Site (41TT653), Titus County, Texas. Document No. 070205. PBS\&J, Austin.

Perttula, T. K., M. B. Trubitt, and J. S. Girard

2012 The Use of Shell-Tempered Pottery in the Caddo Area of the Southeastern United States. Southeastern Archaeology 30(2):242-267.

Thurmond, J. P.

1990 Archeology of the Cypress Creek Drainage Basin, Northeastern Texas and Northwestern Louisiana. Studies in Archeology 5. Texas Archeological Research Laboratory, The University of Texas at Austin.

Weinstein, R. A., D. B. Kelley, and J. W. Saunders

2003 Introduction. In The Louisiana and Arkansas Expeditions of Clarence Bloomfield Moore, edited by R. A. Weinstein, D. B. Kelley, and J. W. Saunders, pp. 1-213. The University of Alabama Press, Tuscaloosa and London. 